\title{
PROPERTIES AND TESTS OF IOWA BUILDING STONES.
}

\author{
H. F. BAIN.
}





\section{PROPERTIES AND TESTS OF IOWA BUILDING STONES.}

BY H. F. BAIN.

\section{CONTENTS.}

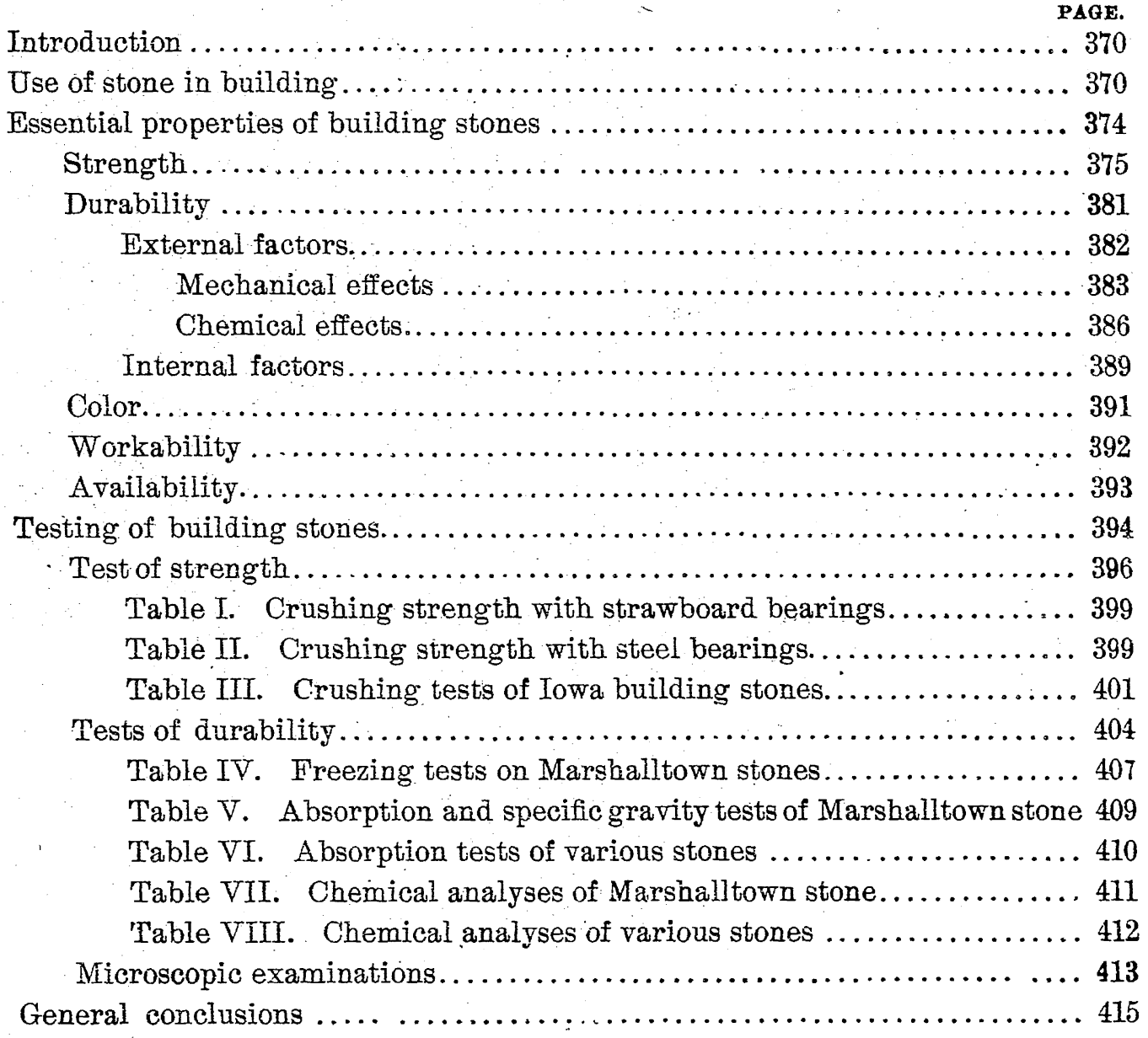




\section{INTRODUCTION.}

At the organization of the present Survey it was planned to issue a series of special reports, each devoted to one subject and covering the general features of occurrence, properties, testing and use of a particular mineral product. In pursuance of that plan the report on coal deposits, forming the second volume of the present series of reports, was issued in 1893. Since that time the energies of the Survey have been principally devoted to areal work. In the course of the latter considerable material relating to building stones has accumulated. Some of the most important quarry regions in the state have been visited and notes on them printed in connection with the county reports. The need has been felt for a more general discussion of the properties of building stones and of the best methods by which they might be readily determined. It is not thought best at this time to publish a complete report on the subject, particularly in view of the uncertainty which prevails as to the methods and value of testing stone. The present paper is accordingly preliminary in its nature and designed to meet a local and immediate want. A portion of it was some time since published in the Monthly Review of the Iowa Weather Service, and certain of the analyses and tests have been printed in the Survey reports. A few have been added, for purposes of comparison, from outside sources and some are now published for the first time. In the work of testing the Survey has had the invaluable aid of the professors at the Iowa Agricultural College and at Drake University, as noted herein.

\section{USE OF STONE IN BUILDING.}

In all times and in all countries when man would raise a great and enduring work, stone has been employed whenever it could be obtained, and in our time and country if we would erect a great public building, a noble university or a stately church, we rightly choose the same material. For the smaller 
buildings, where economy of money is more essential, and the total life of the building of less consequence, cheaper and less durable materials are rightly used. There are also in our country, regions where stone is so rare or of such poor quality that building rock if used at all must be shipped in. Here the cost of transportation will always place it at a disadvantage in competition, with other materials, and preclude its use for any but the most expensive structures. In such areas wood and clay goods become its rivals even within its own proper sphere, but as a rule there is but little competion. Each building material is within its own sphere supreme. For cottages and individual buildings of small size wood must always be most largely used even though equally good effects might be produced with either stone or brick; for city residence blocks and store and office buildings, clay goods are usually to be preferred; but for the larger and more massive individual buildings, where dignity and permanence are valued, stone must always stand supreme, the best building material.

In the selection of the best stone for an individual piece of work our architects and engineers have a wide range of choice. There is hardly a state in the union which does not produce a considerable variety. All the different sedimentary and erystalline rocks are available in the markets of any of our larger cities. To choose wisely from this wealth of material is often a perplexing task. This is true because of the vast interests concerned. Works in which stone is used are rarely those in which small amounts of money are involved. A single contract may make the difference between success and failure in the development of a property. In any event a large contract will keep the whole quarry force busy for some time. Thus large personal and economic interests are involved.

Our engineers have before them a more difficult problem than that faced by the Egyptains and other early workers, in the matter of climate. Not only is our climate in itself more trying than that of the semi-tropical southern countries in which the earlier builders worked, but the great size of our 
country and the modern development of transportation facilities results in a given stone being far more widely used than was any from the ancient quarries. We nolonger build from stone quarried within a few miles of our building site and hence can not argue that the rock having stood for untold centuries in the quarry may well be expected to stand in the building. Our stone may be shipped so far as to be used under totally different climatic conditions from those affecting it in its native exposures.

Again, modern conditions of life are producing a marked effect on our climate. Particularly is this true in our cities where under present conditions so much of the stone must be used. Our universal use of steam, the great amount and often poor quality of the coal burned, the imperfect combustion obtained, the large number of industries which, in the production of their wares, use chemical processes of some nature, all exert a marked influence on the purity of the air. It is doubtful if any stone used by the older builders was ever called upon to stand the insidious influence of so tainted an atmosphere as that to which our stones are exposed as a result of purely artificial conditions alone. This, coupled with the many trying natural conditions of humidity, variation in temperature, wind action and unequal settling, all make the wise selection of stone a matter requiring much thought and a wide range of information.

The very variety of material is in itself confusing. Such wide differences exist in the nature of different rocks that choice between them is not always simple. The property which, in one stone or in one position, may be an advantage, becomes under other circumstances a positive disadvantage.

A rock is not a simple substance. It is not even a definite chemical compound and is very rarely a simple mineral substance. It is rather an aggregate of minerals which may or may not be themselves simple substances, and which, in fact very rarely, are simple in composition. In strict scientific 
sense rock is defined by Geike as follows:" "A mass of matter composed of one or more simple minerals, having usually a variable chemical composition, with no necessarily symmetrical external form, and ranging in cohesion from loose debris up to the most compact stone." It is in this sense that the word rock is used in geology. In common usage, however, the term is restricted to consolidated beds. It is also true that the word rock is more commonly used in speaking of large masses while still in the ground; while to smaller pieces and to the quarried and dressed product, the corresponding term stone is applied.

There is an immense number of varieties of rock. The classification of these varieties may be upon a number of different bases. It may be (1) a classification based upon composition, either chemical or mineralogical, yielding such names as calcareous and plagioclase rocks; (2) it may be structural and lead to such terms as stratified and unstratified; (3) it may be genetic, and so we have volcanic and organic deposits or rocks.

Without attempting a complete or thoroughly scientific classification it will be sufficient for present purposes to consider rocks as either (1) Crystalline or (2) Clastic.

Crystalline rocks. - In this class may be placed all those rocks in which the constituents exhibit wholly, or to a marked degree, a crystalline nature. It includes such rocks as granite, gneiss, syenite and other similar forms. The granite bowlders and related rocks found in the drift and sometimes utilized in Iowa, belong to this group. It is not, however, in this state an important class, most of the stone belonging to it and used here being imported.

Clastic rocks. - This series includes the major portion of the rocks of Iowa. A clastic rock is one which is made up of small fragments of pre-existing rocks newly cemented together. It may, in time, become so changed through metamorphism that it is indistinguishable from a rock which was

*Gelke: Text-book of Geology, p. 61, third Ed., London. 1883. 38 G Rep. 
originally crystalline. A very great number of rocks which are usually classed with the crystallines and studied with them belong in origin to this group. An example of this occurs in our state in the Sioux quartzite. This rock is known to the trade as the "Sioux Falls granite," though it is in reality not a granite, either in composition or origin, but rather a sandstone which has been changed by the secondary growth of the quartz grains into a very hard, closely compacted crystalline.

Similar examples may be found in the limestone series. Marble is but limestone which has been re-crystallized through metamorphism. We have in Iowa no extensive deposits of true marble. There are, however, small areas which show the beginning of the change and frequently bodies of rocks of quite thoroughly crystalline type are found. In order to distinguish these phasal developments from crystallines in the ordinary usage of the term they may be called sub-crystalline. The clastic rocks of this state form two main series; (1) sandstones, (2) limestones. The quartzites may be considered as a subordinate group under sandstones, and the gypsum, while not a limestone, may, because of its closely related origin and small importance as a building stone, be classed with them. The clays, gravels, shales, and similar beds, while as truly rocks as any of the foregoing, are not usually considered as building stones.

\section{ESSENTIAL PROPERTIES OF BUILDING STONES.}

Stones vary greatly in their properties. Some are strong while others are weak. Hard and soft varieties are found. Their composition also varies. As stones are not all alike it follows that all stones are not equally adapted to use for building purposes. A given bed may produce excellent material for lime or cement, and yet the stone may be of no value at all when cut and laid in the wall. It can not be said that the conditions which govern the value of stones for 
building are thoroughly understood, and yet they have been studied by many investigators. The factors which condition the value of a quarry stone, or the properties which are essential in a building stone, may be conveniently considered under five heads: (1) strength, (2) durability, (3) color, (4) workability, (5) availability.

\section{Strength.}

In common with all building materials, the value of stone for building purposes is very largely dependent upon its strength. Indeed, this factor is in stone most fundamental, as the material is the one invariably chosen where the demands upon it are to be most severe.

Strength may be defined as the power of resistance to strain; the latter being any change of form or dimensions due to stress. There are in all five kinds of strain to which bodies may be subjected; tensile, crushing, shearing, transverse and torsional. For present purposes the latter may be entirely neglected.

Tensile strain is the deformation of a body resulting from stress due to pulling. It is the measure of the expansion which a body may undergo, and is usually expressed in terms of the amount of force necessary to pull it apart, or to expand it in a certain definite amount. The amount commonly chosen is that necessary to double the length of a unit rod, and is called the modulus of elasticity, or simply Young's modulus. The crushing strain is the deformation of a body due to compression. It is measured in terms of pounds-pressure per square inch necessary to rupture the stone. A shearing strain is the deformation which a homogeneous body undergoes, without change in volume, by the application of some external force. Transverse strain is that produced in a beam by a force at right angles to its length.

Stones used in building are exposed to all these strains and the value of a stone must, to a certain extent, depend upon its power to resist them. Whenever there is a change of tem- 
perature, the stone must and does contract or expand, and thus tensile strain is induced. The amount of expansion and contraction per degree of temperature has been measured for various kinds of stones. Adie* found that one inch of granite expands .00000438 inches per degree of increase of temperature, and that the corresponding increase for marble is .00000613 inches. Bartlettt reports as a result of measurements made in 1830-1831, under the direction of Colonel Trotter, the following corresponding figures.

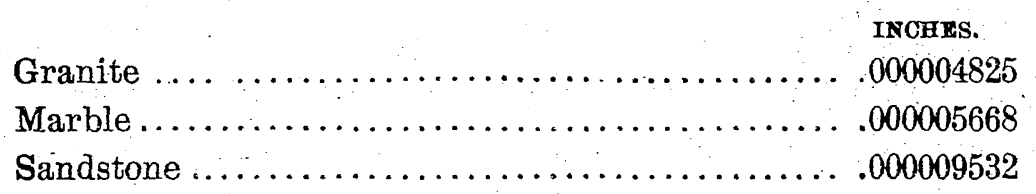

Accepting the latter figures, it will be seen that in Des Moines, where in 1893, the maximum difference in temperature was $111^{\circ}, \ddagger$ there is a total difference in the height of a granite shaft 100 feet high of .6426 inches at these extremes; and that in a granite wall 300 feet long there would be a lateral give and take of 1.9280 inches. For marble, the figures would be respectively .7549 and 2.2649 inches. While measurements on common limestone are not available, its rate of expansion may be safely assumed to be at least as great as for marble. The expansion of sandstone is still greater, and in the case mentioned would be 1.2696 and 3.8089 inches.

Such a strain will be readily seen to cause considerable wear and tear in stones. It has been shown to be sufficient cause for the pulling of the stones away from the cement, and so opens the way for decay. An examination af the seams along the sandstone courses of the Capitol building at Des Moines, in January, 1895, showed that there was at points an appreciable space between the stone and the cement. An examination of the same seams in the following July showed that they were tightly closed. It seems not improbable that in large constructions where different kinds of stone are used

\footnotetext{
*Trans. Roy. Soc., Edinbureh, vol. XIII, p. 366.

†Amer. Jour. Sci., (1), vol. XXIr, pp. 136-140. 1832.

łnn. Rep. Iowa Weather Ser., p. 59. 1893.
} 
in separate courses, there may be an actual movement of one course on the other.

It is also to be remembered that when one face of a structure is exposed to the hot rays of the sun, the other may be receiving a cool breeze, so that an important difference in temperature may be noticed at opposite ends of a long building, and that in winter there may often be a difference of $70^{\circ}$ or more between the temperatures inside and outside of a building. This, of course, causes unequal expansion. It is well known that Bunker Hill monument follows the sun around each day, so that a pendulum suspended from the center of its top, described an ellipse with a major diameter of nearly half an inch. Probably the most severe tensile strain to which stones in a building are subjected is that produced by the freezing of water in its crevices. This pressure is as much as 138 tons to the square foot.

There is, perhaps, no strain the presence of which is more instinctively recognized than the crushing strain. It is at once evident that if one stone be placed upon another the lower stone will be compelled to support the weight of the overlying mass. Taking the weight of granite at 165 pounds, sandstone at 140 pounds and limestone at 150 pounds per cubic foot, it will be seen that in a column 100 feet high; there is a pressure at the base of $16,500,14,000$ and 15,000 pounds respectively. This seems, at a glance, to be large, but is in reality only 114, 97 and 104 pounds per square inch respectively, while the crushing strength of these stones is usually not far from one hundred times these amounts. As long since pointed out by Gilmore, ${ }^{*}$ however, the influence of superincumbent weight is not felt so much in vertical lines of strain, but must always be resolved into oblique strains, and. a stone which would easily withstand a great crushing force may readily yield to the same force, resolved into transverse and shearing strains. This accords well with the results

*Rept. on Building Stones, p. 23, Van Nostrand, New York. 1876. 
of practice, in that stones rarely yield to direct crushing, but rather fail, when they do fail, through cracking or being pushed out of line.

Stone usually yields but slightly to shearing strains. The elasticity of such rock as is used for building purposes is low, while its tensile strength is high. It follows that when a shearing strain is present it usually leads to rupture rather than bending. It is, however, a mistake to consider stones as altogether lacking in elasticity. To a limited degree it is present and often exhibits itself in a marked manner. Hodgkinson experimented* on the elasticity of stone by supporting slabs at the ends and applying horizontal force. It was found that the defect of elasticity is nearly as the square of the weight. Geikiet has called attention to evidences of the elasticity of marble slabs as seen in the Scottish cemeteries. More recently Winslow $\neq$ has noted similar phenomena as exhibited at Jefferson City. From measurements on eertain marble slabs seen in the cemetery there he has calculated that a long piece of this marble two inches thick could, under continued stress for a period of twenty-five years, be bent to the form of a circle having a diameter of less than eighty feet.

This tendency of stone to warp often leads to considerable trouble and expense. During the work of the Capitol improvement at Des Moines, Mr. E. W. Crellin, the engineer in charge, found that in a few months the heavy granite blocks used for steps frequently became so bent out of shape that it was necessary to redress portions of them before they could be set. In mountainous regions nothing is more often seen than flexed strata. It is usually assumed that at the time these beds were bent they must have been under heavy pressure, and probably were, at the same time, more plastic. It seems possible that the element of time has not been sufficiently taken into account. If a granite block, simply from its own

* Athenaeum, No. 1353, p. 1165, London. 1853; Jour. Franklin Inst, (3), vol. XXVII, pp. 3536. 1854 .

+ Geol. Sketches, pp. 170-172

$\ddagger$ Amer. Jour. Scl., (3), vol. XLIII, pp. 133-134. 1892. 
weight and because of unequal support, will bend so as to necessitate re-surfacing before use, it seems not improbable that very slight pressure, if long continued, might lead to very important shearing.

The strains to which stones are most commonly subjected, and under which they frequently fail, are transverse strains. It is very rare indeed that one sees a crushed stone, but cracked stones are more frequent. The cracking is the expression of the transverse strain. If a stone be overloaded at one end, or if it be insufficiently supported at any point, it is subjected to transverse strain. With the low limit of elasticity of this material it can rarely accommodate itself to the unequal pressure, and so gives way. It will be readily seen that if for any cause a stone, when used in a large construction be in part unsupported, there will be an enormous pressure upon the unsupported part. To resist this pressure it has nothing except its own tensile strength. The most frequent cause of such inequality is the failure of the foundation to settle equally. If in any massive construction the foundation goes down more rapidly at one point than another, the best of stones will fail unless the factor of safety has been taken very high. More rarely the fault is in the construction of the wall, the stones being imperfectly laid. These are matters which rest entirely with the judgment and ability of the supervising architect.

The tendency of all strain is ultimately to tear apart the component particles of a substance. The abilty to resist this tendency is the measure of the strength of a substance. "In stone this ability may be due to a number of different properties. In general it is dependent upon the strength of the individual particles or crystals and upon the strength of the bond.

The different particles of a rock may be bound together by several means: chemical, mineralogical, by simple contact or by means of a cement or bond. The first two means of union are not usually affected by stress but are more subject to the 
influence of decay. As a general rule the average crushing strength of granites and similar rocks having a mineralogical union, as contrasted with the clastics which have a true cement or bond union between the particles, is greater. This is not, however, always true. In certain cases clastic rocks are firmer than crystallines:

When the particles of a substance cohere through simple contact, the force necessary to separate them increases with the surface of contact. This is, in the case of grains of sand or clay, most largely dependent on the size of the particles. If the particles are small the interspaces are correspondingly diminished and the different pieces of mineral touch at a greater number of points. Thus it follows that, other things being equal, fine-grained rocks should show greater strength. In practice the range of variation in the size of the particles is usually so small as compared with the variation in other regards that this is rarely important. It has, however, been noted by Hatfield* that in the case of crystalline rocks the coarsely crystallized specimens crush more easily, and, while the conditions are somewhat different, it is not impossible that if the other factors could be eliminated, similar results might be obtained from experiments on clastics.

The direct controlling factor in the strength of a clastic stone is usually the nature of the bond material. In general the cementing substance found in the Iowa clastic is either argillaceous, calcareous, ferruginous or siliceous. Other cements are occasionally found and still other materials may act as such. One of the most common substances which may be a bond material is water. Its value as such is well recognized in the clay industry and it may be readily tested by trying to mould dry and wet sands. The influence of water is at once apparent in the ease with which the wet sand may be made to hold form. Water as a bond material is of small value, since it soon evaporates and the molded form crumbles. Of the cementing materials occurring in nature, argillaceous

* Jour, Franklin Inst., (3), vol. XXXV, p. 169.1858. 
cement is probably the most common. It rarely, however, occurs alone, but is usually mixed to a greater or less extent with calcareous or ferruginous matter. Calcareous bond material is universal in limestones and not uncommon in sandstones. When a calcareous cement binds calcareous material it is unsurpassed; where it joins argillaceous material it is still good; but where it joins arenaceous particles there are other substances better. Ferruginous cement is rarely found in limestone beds of sufficient extent to be of importance as building material. It is, however, a common cement in sandstones, and here its strength giving ability seems to depend very largely on its purity and the completeness with which it fills the interstitial spaces of the rock.

Siliceous cement occurs both in limestones and sandstones, and in either case contributes greatly to the value of the rock. Indeed it may well be doubted if any rock, crystalline or clastic, has greater strength than a quartzite, which is merely a sandstone with a siliceous cement.

A comparison of the crushing strength of the usual building rocks shows that as a rule their strength will run in the following order, though the exceptions are many: (1) Quartzite; (2) Granite, and a major portion of the crystallines in use; (3) Limestones and marbles; (4) Sandstones with ferruginous and calcareous bond. Siliceous limestone will rank usually at the head of the limestones and occasionally higher.

\section{Durability.}

A property of stone which is equally important with strength, and which is more difficult to estimate, is that of durability. Remembering that stone is rarely used except in buildings where permanence is an important disideratum, it will be at once apparent that whatever properties a building stone may lack, it must be durable. A stone may be ever so accessible, may be easily worked, may have a pleasing color and even a high degree of strength, and yet if it will not last when put in the wall it has no value as a building stone. 
The estimate of the durability of a stone is all the more perplexing because it depends on such a variety of factors both internal and external. It can not be said that these essential factors are well understood and there is probably no material which the architect uses, about which he knows less than stone. Testing the strength of a stone may be done in accordance with well established rules; but estimates of durability can not as yet be made on any well formulated system. It is notorious that some of the worst failures of stone have been in cases where material of excellent appearance has been used. The problem is so large and so complex, and the factors which enter into it are so various, that no single method of testing will apply.

Any estimate of the durability of a stone must take into account a wide range of factors, both external and internal. Both the nature of the stone itself and the conditions under which it is used influence the degree with which it may respond to its environment without destructive effects. Both series of phenomena must be considered and the rejection of the stone may be necessary as a result of either of the two sets of conditions being unfavorable.

\section{EXTERNAL FACTORS AFFECTING DURABILITY.}

There are probably few laws better established in modern science than that organisms are influenced by their environment. This is a law which so far as we know is fundamental. It applies alike to organic and inorganic bodies. Just as surely is it true that as the heavy furred animals of the north come to inhabit a warmer climate they shed their heavier coverings, so granites and other crystalline rocks formed under one condition, upon being transferred to other conditions, slowly but surely adjust themselves to their new environment. It is weil established that under the peculiar conditions present beneath the earth, silicic acid tends to drive out and replace carbonic acid, and that the reverse is true in rocks at or near the sur. 
face. The forms and combinations which were stable in granite when it was formed as a deep-seated rock, became unstable and tend to break down when it is exposed. The same is true to a greater or less extent of all rocks. A deposit which was in a stable condition at the bottom of the sea becomes unstable when forming a portion of the land surface. Hence arises the widespread decay of rocks exposed at the surface; a process which if continued long enough must inevitably cause them to break down into loose beds of gravel, sand and clay.

The processes by which this change takes place are known collectively as weathering, which is not a simple process, but a series of processes. Stones when cut, dressed and used in a building are exposed to these processes for the same reasons and to the same extent that they are when in their native ledge. Often indeed they are subjected in an even greater degree to deleterious influences. Weathering effects are due to both mechanical and chemical processes.

Mechanical effects. - The mechanical processes may be considered as due to three agencies: wind, moisture and heat.

The mechanical effects of the wind are not usually important in the consideration of building stones. That wind when loaded with sand, as it must always be to a greater or less extent, has an abrasive action is a well known fact. Endlich* has called attention to some of the more striking results of such action in Colorado. Merrillt has noted the action of storm winds on the exposed glass of lighthouses. More recently Udden $\ddagger$ has reviewed the whole subject of wind erosion. Where buildings are exposed to the same conditions the action of the wind on the stone in the wall can not but be the same as in the native ledge. Egleston $\$$ noted the fact that in many of the New York churchyards, tombstones may be found which are worn nearly smooth by this agent alone. It very rarely happens, however, that stones in buildings are so

*Bul. U. S. Surv. Ter, vol. Iv, pp. 831-864. 1878.

+Smithsontan Report, 1886, pt. 1i, p. 335.1889.

$\ddagger$ Jour. Geol., vol. II, p. 315, 1894.

§Amer. Arch., p. 13, Sept. 5, 1885. 
exposed. They are usually protected from the direct action of the wind so that its influence is less in the work of abrasion and more in bringing in contact with the stone certain injurious gases or large amounts of moisture which may be present in the air. The action of the gases is chemical and will be later considered. The erosive action of water is one of the most familiar effects seen in nature. The deep channels worn by the rivers and the general wearing away of the exposed land surface are marks of its power. It is not often, however, important from the present point of view. Except when used in bridge piers, dams and similar constructions, building stones are seldom exposed to erosive action. In large buildings certain cornice stones frequently serve for gutters, but in such cases they are usually protected by a metal surface; preferably copper.

The principal mechanical effect of water is accomplished by the aid of temperature changes in what is known as frost action. All rocks are more or less porous and hence are capable of absorbing a greater or less amount of water. This amount has been measured for a considerable number of rocks by Merrill, Hopkins, Winchell, Cutting, Heinreich, and others. In general the absorption is, for granites, from the merest traces up to ${ }_{1 \frac{1}{10}}$; for limestones the amount varies between $\frac{1}{18}$ and $\frac{1}{678}$; for sandstone from $\frac{1}{8}$ to $\frac{1}{37}$; dolomite shows about the same absorption as limestones, and quartzites average with the granites. When water freezes it expands with a force which at $30^{\circ} \mathrm{F}$. is over 1,900 pounds per square foot. For lower temperature this force is greater. If the water be inclosed the force becomes sufficient to break most'stone. Indeed frost is probably the principal agent in breaking down large rock masses. Jordan speaks of the Matterhorn as but a wreck-"the core of a far greater mountain whose rocks have been hurled down the valley,"* and again says: "The whole outer coat of the mountain is loose, scarcely a rock anywhere on the Swiss side being firmly attached." $\dagger$

* Sciences Sketches, p. 212.1888.

† Ibid,jp. 218. 
Water penetrates all the cracks of a rock and upon being frozen rends it apart. Certain of our building stones seem particularly susceptible to this action. Usually a fine-grained, compact stone will absorb less moisture and suffer less from frost than a more open textured stone. As pointed out by Merrill* this is not always true. In the case of the open textured stone, though it takes up water rather readily, it parts with it equally readily and at the same time the whole force of the expansion need not necessarily be expended in pushing apart the particles of the stone. Instances of this may be seen in our own quarries. Certain portions of the Saint Louis limestone occasionally quarried in the central portion of the state are particularly unable to withstand frost action. Yet the stone is to all appearance a very fine-grained, compact rock. In neighboring quarries a coarser textured Augusta stone stands the frost better.

The action of the frost is usually beneficial to the quarryman. In granite regions quarries are often worked for years merely in the overlying scattered boulders before the solid rock is reached. It would be impossible profitably to quarry the Sioux quartzite were it not for the aid of the frost and the joint cracks.

The principal effect of changes of temperature on stone is doubtless the frost effect just noted. Aside from any such subsidiary action temperature changes may have themselves important effects on the life of the stone. The expansion and contraction due to temperature changes have already been noticed. It is obvious that the frequent repetition of these changes in volume must affect the durability of the material. A strain which may be eașily met once, if repeated often enough will cause rupture. The expansion of the different components of stone differ and thus they crowd unequally against each other. The different portions of a stone may be unequally heated, as when the outside temperature is $24^{\circ}$ below and the inside temperature of a building $70^{\circ}$ above. 
In all such cases the stone must be weakened. If stones be heated and then suddenly cooled they will break. Livingston found that in Africa stones heated during the daytime cooled so rapidly at night as to throw off sharp angular fragments, and Stanley states that a cool rain falling upon the sun-heated rocks caused them to split.* An interesting instance of the effect of heat was shown at the old North Avenue viaduct in Baltimore. In 1892 an oil car burned at the foot of one of the abutments. The effect of the heat was to bring out in a few hours upon the masonry the characteristic spherical weathering shown on long exposed rock faces. Julient has called attention to the greater weathering on the face of a building which is exposed to the greatest ranges of temperature and Merrill $\ddagger$ has made similar observations.

Chemical effects. - With the exception of frost action the most important agencies in the weathering of stone are chemical. The air is at all times charged with various gases some of which are destructive to stone. When the stone is exposed to water a larger number of chemical agents may be at the same time brought into play because of the substances which it may carry in solution. The attacks of these chemical agents are the most insidious because unseen, and yet they form a most important factor in the life of a stone.

The various chemical processes which take place during the weathering or decay of a stone may be summarized as follows: (1) Solution; (2) Oxidation; (3) De-oxidation; (4) Hydration; (5) Carbonization.

Solution is one of the most familiar chemical processes and one which is constantly taking place wherever rocks are exposed to rain water or moist air. Gypsum, which has been used at Fort Dodge to a very limited extent as a building stone, is readily soluble in a ratio of about 1 to 400 in water and is soon worn away. Of the stones ordinarily used for building purposes limestone suffers most from this process.

* Cit. by Gekie, Text-book, 3rd Ed., p. 329. 1893.

†Tenth Oensus, vol. X, Rep. on Bullding Stones, p. 380. 1889.

ॠ Op. Cit., p. 332 . 
It is soluble to the extent of about 1 to 1,000 parts in water charged with carbonic acid gas.

The air at all times contains more or less moisture and some carbonic acid. In cities the percentage of the latter may become relatively high. Pfaff* has carried on experiments on the rate of weathering of limestone. The material used was the Solenhofen lithographic stone which is very similar in texture and appearance to white limestone found in the Pella beds of the Saint Louis. A plate of this rock was exposed to weathering influences for two years and from the loss in weight it was calculated that such stone weathered away at a rate of one meter in 72,000 years, or about one foot in 21,300 years. Observations made on dressed stones in England, place the rate at from one foot in 240 years to one foot in 500 years. The rate evidently varies rapidly and is apparently dependent more upon the evironment than the composition of the stone. The latter is, however, more or less to be taken into account. Dolomite is less soluble than limestone, which is one of the reasons why it usually gives better satisfaction as a building stone.

Sandstones are only very slightly soluble. The principal constituent, quartz, is not affected by any of the solutions to which building stones are ordinarily exposed. The bond material may, however, suffer from a number of them. The great durability of quartzites and of siliceous limestones is perhaps due more to the insoluble nature of the bond than to any other one factor. On the other hand, an argillaceous sandstone may break down readily, and it is a very common thing to find around a sandstone bowlder a little heap of loose sand grains which are the result of such weathering.

Oxidation is one of the most common and most active chemical processes. Oxygen is present in the atmosphere and is also a very common constituent of rain water. It is a very active chemical substance and has a great affinity for many of the minerals commonly occurring in rocks. In the crysta

\footnotetext{
*Zeit.; D. D. Geol., Ges., bd. XXIV, p. 405. 1872.
} 
line rocks the ferro-magnesian compounds especially tend to break down in its presence and to form new substances. In the clastic rocks its influence is also often felt. One of the most frequent impurities of limestones, for instance, is iron pyrites or sulphide of iron. The action of the oxygen upon this substance is first to form the sulphate of iron. In the presence of water this gives rise to iron-oxide and sulphuric acid. The former disagreeably stains the stone while the latter is an active solvent of limestone. Even in so impervious a stone as quartzite the action of oxygen upon the iron present may be detected.

De-oxidation may, under certain circumstances, result from rain water charged with reducing agents. These usually come from the decay of organic matter. The tendency of these reducing agents is to take away the oxygen present; particularly from the iron oxides. This results in discoloration. If a limestone contains magnesia, it will tend, in the presence of sulphuric acid, which may be present in the air as a result of the combustion of impure coal, to form a magnesian sulphate. This will manifest itself usually in the form of efflorescence. De-oxidation is an action not often seen on building stones, though frequently observed on native ledges.

Hydration, while occasionally observed in quarry rocks, is not important in the consideration of building stones.

Carbonization is a common form of alteration among crystalline rocks. A familiar example is seen in the alteration of feldspar to kaolin. It is the expression of the general law that under surface conditions carbonic acid tends to drive out silicic acid. It is not usually an important factor in the alteration of sedimentary rocks, as they rarely contain any great quantity of material subject to such action. In limestones the earbonization of the material has already taken place before the stone was formed. Sandstones rarely contain suffcient alkaline matter to be subject to attack, though certain arkose sandstones might suffer from this action. Such stones 
as are commonly found in Iowa will suffer most chemically from solution and oxidation.

The influence of organic matter in hastening the decay of stone has been very frequently insisted upon. Robert* has called attention in Le Monde to the action of Lepra antiquitatis, a small cryptogamic plant, in promoting decay of rocks. While it is undoubtedly true that the decay of lichens or other plant forms gives rise to organic acids which aid in breaking down a rock and reducing it to a soil, it is also true, as has been suggested, that the lichens and similar plants often form a covering which preserves the rock by protecting it from undue temperature changes. On the whole it seems not improbable that the deleterious effects of plants on building stones have in the past been too strongly insisted upon.

\section{INTERNAL FACTORS AFFECTING DURABILITY.}

The life of a stone is as much dependent upon internal conditions as upon its environment. The selection of a stone whose internal structure is such as to enable it to withstand the unfavorable conditions of modern eity life is the problem which confronts our engineers and architects. The internal conditions of a stone which affect its life are mainly the nature of the constituent minerals and the state of aggregation.

While the total number of mineral species is quite large, the number which commonly occur as rock forming minerals is relatively small. The number which occur in rocks, such as are found in Iowa, is smaller still. Among those present and most important are quartz, calcite, aragonite, dolomite, gypsum, pyrite and hematite. In addition to these a number of others are found as impurities in the clastic rocks. In the crystallines, which as has been said are occasionally quarried - from the drift bowlders, the whole series of feldspars, micas, pyroxenes, etc., are present.

The most common constituent of Iowa stones is calcite or calcium carbonate. This is an original constituent of the 
limestones and is found mixed with various proportions of argillaceous impurity. It also occurs as a secondary product in veins running through certain stones. A good example of this may be seen in the Mount Vernon quarries, where the buff dolomite is cut by white veins of caleite. In this instance the calcite resists the weathering influences better than the country rock and so stands out on a weathered surface. Aragonite, a different form of calcium carbonate, also occurs.

Dolomite is a very common constituent of Iowa stone, the great ledges quarried in the Niagara being very largely dolomitic. The Galena limestone is also dolomitic, as is indeed a very large portion of Iowa limestones. There is a belief, borne out by practice, that dolomitic stones are better for lime burning purposes than pure limestones. They are also preferred for use as building stones. Magnesian carbonate is less soluble than calcium carbonate and hence there would appear to be a good reason for preferring it. In opposition to this view C. L. Dresser* points out that in cities where a great deal of coal is burned, such as Leeds where his observations were made, the sulphuric acid in the air unites with the magnesia to form magnesian sulphate. This is in wet weather absorbed by the brick or stone and in dry weather crystallizes and splits off the face of the rock.

Quartz is the major constituent of sandstones. It is a most durable material though by no means fire-proof. Gypsum is not important as a building stone. Pyrite is frequently present as an impurity and may seriously affect the durability of stone. Hematite is present as a cementing material in sandstones, though limonite is probably more common.

A second important factor in the durability of a stone is the state of aggregation. The influence of various kinds of bond upon the strength of a stone has already been pointed out; their influences upon its life are no less important. It is stated that the air changes the cement of certain sandstones from an insoluble to a soluble condition and that practice

*London Buflder, No. 863; Oit. Jour. Franklin Inst., (3), vol. XV, p. 56. 1860.

+Van Nost. Eng. Mag., vol. III, p. 296. 1872. 
shows* that, in certain cases on the ground level, porous limestones decay more readily than porous sandstones as a result of the difference in composition. It will be recognized that if a 9-inch cube of stone absorbs three pints of water in fortyeight hours, as has been notedt, the stone is exposed to far greater damage from both temperature changes and chemical action, than one in which the absorption is practically nothing. Texture is thus an important factor in the problem. General experience seems to have proven that as a rule fine-grained rocks are most durable. A fine, even texture does not allow the various injurious gases and solutions so readily to penetrate the stone and hence it is better prepared to withstand their attack. Homogeneous rocks will weather most evenly. This is a decided advantage, as unequal weathering, by weakening certain portions of a stone, may induce strain both in it and superincumbent blocks, thus impairing the strength and shortening the life of the rock.

\section{Color.}

Among the minor properties of building stones which are essential factors in their popularity and value, few are more important than color. The red sandstones are not always of greater durability or strength than similar stone of other color, and yet the reddish-brown stone was for many years most popular. This was probably due to no small extent to the fact that the stone harmonizes so well with the usual tints of brick. The choice of stone, so far as color is concerned, is in the main a matter of taste alone. Recently the light colored stones have been most popular. The darker hues give a gloomy and massive effect, while lighter tones or combinations of colors break this up. It is not always a mere matter of choice, however, since certain colors are more apt to change than others The chief coloring matter in rocks is iron, and it depends upon the form in which this occurs whether the color will prove 
lasting. If the iron be in the form of sulphide, carbonate or protoxide, it is subject to oxidation, and the bluish or gray color changes to a brownish or reddish. This is often seen in the red surface of weathered limestone and other rocks. The deep red rocks thus have a permanence in color not possessed by the others, which is another good reason for their use.

Uniformity is important in color as in other properties, the more so as it is usually an indication of uniformity in composition and properties.

\section{Workability.}

The workability of a stone is dependent mainly upon its rift and grain. Nearly all rocks break more readily along certain planes than others. The whole art of quarrying is based upon this fact and consists in taking advantage of these planes. Only a very small portion of the stone which now reaches the market could ever be profitably taken out of it were it not for this fact. The cheapness and ease with which the Sioux quartzite can be broken up into paving blocks is due to the presence of these planes.

In unaltered clastic rocks the bedding or stratification planes are usually most prominent. These are planes of sedimentation and are due to variations in that process. In the stone as quarried, this division plane is known as the "rift" as Merrill uses the term. At right angles to this is the "grain." There may be more than one set of planes shown by the grain so that the stone may tend to break in more than one plane. If a third direction of easy splitting is present it is sometimes referred to as the "head." Thus a rift or bedding surface may be marked off by the grain in squares, triangles, diamonds or irregular polygons. It is not unusual to find the grain running along two sets of planes at rightangles, or nearly so. When this is true, by a little care the stone is readily quarried out in blocks ready for use. In some cases the rift is so marked and the rift-planes so even that the stone requires no further surfacing. 
The origin of the grain of a stone is a matter not clearly understood. In a more general sense the planes of grain are known as joint planes. To account for them a number of theories have been proposed. It is more usual to regard them as being simply the result of the tendency of stone to contract either when cooling from a molten condition in the case of crystallines, or, in clastics, when losing a considerable portion of their water content. Crystalline and magnetic forces as well as torsion and earthquake shocks have been called in to aid in the explanation. Very probably they are due to a considerable extent to stresses resulting from dynamic action. In regions of disturbed strata the whole series of phenomena known as cleavage, fissillity, foliation, etc., have been shown by Van Hise* to be dependent upon common causes and to afford accurate means of discriminating the structure of the strata. The extent to which a stone has been altered by these forces conditions at once its use and the methods by which the quarry may be worked. A soft stone, but little altered and in massive condition, is, for example, best worked by channelers, and is particularly subject to injury in blasting.

\section{Availability.}

The final factor in the value of stone, as in all other material, is its availability. It may be ever so excellent in every regard and still if it exists in insufficient quantity, or does not enjoy good transportation facilities, it can not be used.

One important thing to be borne in mind in selecting a quarry site is that it must afford, as far as possible, a uniform material. All stones vary slightly from ledge to ledge, or in different parts of the same ledge. It is impossible to attain absolute uniformity, yet by careful selection a practically uniform grade of stone can be placed on the market. In an industry such as this, where so much depends on capturing and holding the popular fancy, uniformity of product is of more than usual

* Sixteenth Ann. Rep. U. S. Geol. Surr. 
importance. In this regard the heavy sandstone beds of the coal measures have an important advantage. They frequently show very slight bedding only, and are practically massive. They may be worked with channelers and sawmill in the same manner that marble is usually quarried.

Transportation facilities are not less important to the stone industry than to others. The presence or absence of a railway is often the controlling factor in the value of a quarry site. In our own state, the railways have been mainly built to accommodate through traffic. As the cities grow in size and wealth, and larger and more massive buildings are erected, there must be an increased demand for building stone. This will create a better local market and result in the steady development of the local stone industry. With the steadier demand it will be possible to build the long switches and local lines which are necessary in order to open up the many good ledges now untouched, and enlarge the output of the quarries already in operation.

\section{TESTING OF BUILDING STONES.}

It has been shown that the properties of stone which are to be considered in construction work are various, and that the life of the stone will depend, not only upon its own inherent characteristics, but upon the conditions under which it is used. Neither of these sets of factors is under the control of the engineer, so it becomes his problem to select the right stone for given conditions. As an aid in this selection, various tests have been formulated. In general, the tests have been made mainly with reference to strength and durability, and have included the determination of the crushing strength, absorption ratio, resistance to fire and abrasion, chemical analyses and microscopic examinations. Frost tests, both natural and artificial, have been widely applied and many special tests have occasionally been made.

It has been proposed to combine the results of these various tests, working out a formula for the value of a stone and com- 
paring them by means of this. While this is doubtless the end to be aimed at, it is exceedingly doubtful whether we yet know enough of the real conditions of the problem and whether our special tests are not too clumsy to make such attempts of final value.

For example, probably the best stone can be torn to pieces by prolonged frost action, either natural or artificial, and yet the same stone may give excellent results in practice. We do not know the ratio existing between the action under natural conditions and that obtained during the test, because the time element must, of necessity, differ and it is not known how much the intensity must be increased in order to counterbalance the time. It is also a question whether intense frost action; for short and rapidly succeeding periods, produces exactly the same results as the milder natural action extending through longer time. So, too, in the matter of strength, probably no stone of sufficiently sound appearance to warrant its use in a wall, ever failed by simple crushing. Many stones, however, of moderately high crushing strength, have, from various causes, failed in practice. As a rule the failure is not in strength but in durability. When a stone cracks it is almost always true that it has been improperly placed and is not equally supported. It should be remembered that the factor of safety is always taken high in stone construction, though this is to some extent an expression of our ignorance of the nature of stone. The whole matter of the testing of stone is in dispute and no general series of tests has yet been formulated. The value of many of the special tests is seriously questionedt, and much uncertainty surrounds the subject. A considerable amount of careful experimentation is yet to be done before definite conclusions can be drawn as to the value. of most of the tests.

*Winchell: Geol. Nat. Hist. Surv. Minnesota, vol. I, pp. $184-191$.

tGarrison: Trans. Amer. Soc. C. E., vol: XXXII, p. 88.1894. 
Tests of Strength.

Tests of the strength of materials are among the most common tests engineers are called on to make. Resistance to the various stresses, tensile, crushing, shearing, transverse and torsional, may all be measured by well known methods and formulas. Some, or all, of these tests are very commonly made upon all materials entering into building. In stone work, the crushing test alone is usually attempted, though occasionally shearing and transverse strain tests are also made. $f$ It is very doubtful whether crushing tests are in themselves of much value. As has been suggested stones are rarely subjected to high crushing stresses. The test, bowever, gives at least a rough approximation to the power of the stone to resist other stresses. It also, to some extent, indicates the power of the stone to resist the splitting action of frost, since that is largely a matter of the tensile strength of the stone. The importance of the test is probably in most cases overestimated and the significance attached to it is an expression of our helplessness before the problem of accurately testing a stone.

The conditions to be observed in testing building stones have been formulated by Gillmore. $\&$ It may be stated that his work, since confirmed by other investigators, shows that the crushing strength per square inch increases in cubes with the area of cross-section, that in prisms of equivalent crosssection the resistance decreases with the height and that the resistance varies also with the nature of the compressing surfaces. In all ordinary construction stone is laid in mortar so that the latter forms the surface which transmits pressure to the stone. In experimental tests smooth steel plates usually form the contact surfaces. It is obvious that the results with steel plates may be quite different from those with mortar, since there may be a greater or less degree of resistance to lateral spread in one case than in the other. Gillmore experimented upon the use of steel, wood, lead and leather surfaces

$\ddagger$ Johnson: Indiana Geol. Surv., 1881.

\$Building Stones of U. S., Van Nostrand. 1876. 
and found that with the same stone there was a marked difference in the crushing strength. Vermont marble, which has about the crushing strength of Anamosa limestone, gave the following percentages.

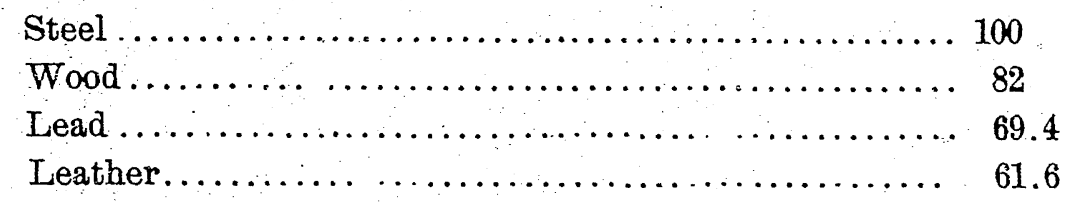

The differences seem to be due to the fact that the smooth steel plates, forming a good contact, resist the tendency of the stone to spread. The wood, having a tendency to spread sideways, induces a tensile strain in the stone. The lead and leather, flowing at low pressures, are driven into the interstices of the stone, acting, Gilmore conceives, as wedges and splitting the stone into numerous vertical prisms. Where, then, a rigid body forms the contact surface, the strain is a simple shearing strain. When the contact surfaces are of material which either flows or splits under smaller stress than that which seems to rupture the stone, a tensile strain is induced. The crushing tests may accordingly be varied so as to give some clue to the power of resistance which the stone may be expected to show the more important stresses.

In some tests made for the Survey at the Agricultural College in April, 1896, experiments were made upon the influence of cardboard cushions upon the crushing strength of the certain stones. The tests were made upon an Olsen testing machine, fitted with adjustable steel plates. The upper plate was fixed but the lower was free to move on a hemispherical protuberance which was accurately fitted into a well lubricated socket. By this device the pressure was equally distributed when the parallelism of the cube faces was imperfect. In the case of the specimens tested with steel bearing surfaces, the tops and bottoms were rubbed down to true planes. Where strawboard bearings were used, this was not done and the surfaces were those left by the saw.

35 G Rep. 
Two stones were tested, one the Anamosa limestone, and the other the Monroe red sandstone. The former is one of the leading building stones of the state, and is quarried from certain beds of the Niagara. It is a fine-grained, light buff dolomite, very minutely laminated and quite free from impurities. Under the microscope, a section perpendicular to the bedding shows a mass of very fine crystalline grains of dolomite with a very few scattered, iron-stained points. The lamination planes are seen to be formed by the crowding together of the grains of dolomite. There is no difference in material, nor is there any observable difference in the size of the particles. Apparently the laminations here are not indicative of heterogenity of constitution. They are clearly not due to any secondary action, and probably mark only the result of various compacting influences operating in the intervals between the deposition of the individual layers. With the exception of the laminations the stone is absolutely homogeneous, and one portion of a block should be as strong as any other portion.

The Monroe red sandstone is from the coal measures, being taken from the lower portion of the Des Moines beds. It is a moderately coarse-grained stone, with some range of color and texture and corresponds in general with the Red Rock stone which has been more widely marketed. The Monroe stone has never been really opened up, as only trial lots and small shipments have been made. As will be seen from the tests, it is an excellent stone and might be used to advantage in all structures similar to those in which brown stone has been so extensively used in the east. Under the mic̀roscope it is seen to be made up of rather coarse and rounded grains of quartz cemented by a matrix of redzbrown,- iron-stained material which, judging from the analysis, is largely ferric oxides, but contains also some aluminous material. The sand grains are rarely in contact; the interstitial areas being usually as large as the cross-section of the individual grains. 
These tests were made on the Monroe sandstone, two being with steel bearing surfaces and one with strawboard bearings, $3 \frac{1}{2} \times 2 \frac{1}{2} x_{32}^{3}$ inches. A number of tests were made on the Anamosa stone, as given in the general tables. Several of these, made on stone from the Champion quarries, are important in this connection.

TABLE I.

Crushing Strength with Strawboard Bearings.

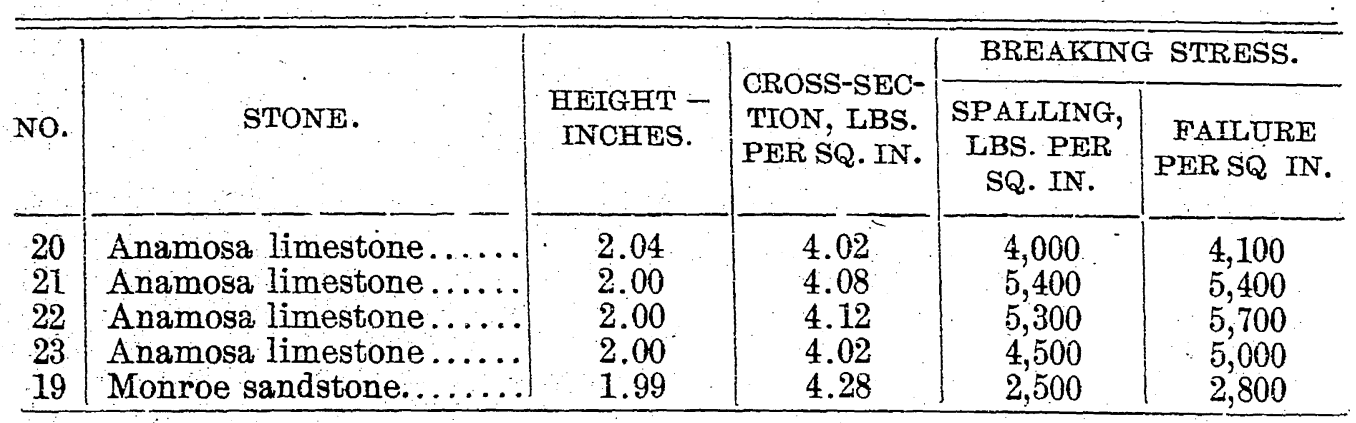

All of these specimens were placed on bed except No. 23, which was placed on edge.

TABLE II.

Crushing ștrength with Steel Bearings.

\begin{tabular}{|c|c|c|c|c|c|}
\hline \multirow[b]{2}{*}{ No. } & \multirow[b]{2}{*}{ STONE. } & \multirow[b]{2}{*}{$\begin{array}{c}\text { HEIGHT- } \\
\text { INCHES. }\end{array}$} & \multirow[b]{2}{*}{$\begin{array}{l}\text { CROSS-SEC- } \\
\text { TYON, LBS. } \\
\text { PER SQ. IN }\end{array}$} & \multicolumn{2}{|c|}{ BREAKING STRESS. } \\
\hline & & & & $\begin{array}{l}\text { SPALLING, } \\
\text { LBS. PER } \\
\text { SQ. IN. }\end{array}$ & $\begin{array}{l}\text { FAILURE } \\
\text { PER SQ. IN. }\end{array}$ \\
\hline $\begin{array}{r}11 \\
12 \\
13 \\
4 \\
5 \\
\end{array}$ & $\begin{array}{l}\text { Anamosa limestone ...... } \\
\text { Anamosa limestone...... } \\
\text { Anamosa limestone...... } \\
\text { Monroe sandstone........ } \\
\text { Monroe sandstone....... }\end{array}$ & $\begin{array}{l}2.01 \\
2.01 \\
1.98 \\
1.96 \\
1.97\end{array}$ & $\begin{array}{l}4.12 \\
4.06 \\
4.08 \\
4.36 \\
4.51\end{array}$ & $\begin{array}{l}4,100 \\
6,100 \\
5,600 \\
3,600 \\
3,700\end{array}$ & $\begin{array}{l}6,600 \\
7,400 \\
7,500 \\
3,600 \\
3,700\end{array}$ \\
\hline
\end{tabular}

From these tables it will be seen that the average crushing strength of three specimens of the Anamosa stone tested with steel bearings, was 7,188 pounds per square inch, and of the same number with strawboard, rejecting the specimens set on edge, was 5,100 , or that the latter method developed 71.17 per cent the strength shown by the former. In the case of the sandstone, the per cent is 
73.99, and the average for the whole is 72.58. The number of experiments was so limited that the possibility of accidental concordance of variation is not altogether eliminated, but the fact that the phenomena all point in the same direction and that the results accord with what would be expected from Gilmore's tests, give one some confidence in their substantial correctness. It is interesting to note that the specimen of the Anamosa stone set on edge stood approximately the same pressure as those set on bed and tested in the same manner. This is rather surprising and indicates apparently that the difference in the strength of this stone on edge and on bed is less than the difference in the result obtained by testing with steel and strawboard; that is, less than 30 per cent. * This confirms the results of the microscopic study which indicate that the lamination planes of the stone are not planes of weakness except as they may allow more ready penetration of moisture. It may be, though, that under frost action they would lead to the splitting of the stone. If, however, we are to take the test with the strawboard as roughly measuring the tensile strength of the stone, it would appear that in this case, frost action would probably not be important. In the case of so fine-grained a stone as the specimen tested, this may be assumed to be true and, as a matter of fact, in this case is true. This indicates one method of varying the crushing test, which is simple and easily applied, so as to yield important information other than that relative to the mere strength of the stone.

The various Iowa building stones have been, from time to time, tested to determine their crushing strength. For convenience of reference the results of these tests, so far as they are known, have been brought together in Table III.

The tests at the Agricultural College were made on the Olsen testing machine with adjustable bearings and with steel surfaces unless otherwise indicated. All specimens were sawed, and rubbed to a smooth surface, and were approximately $2 \times 2 \times 2$ inches. 
TABLE III

CRUSHING TESTS OF IOWA BUILIDING STONE.

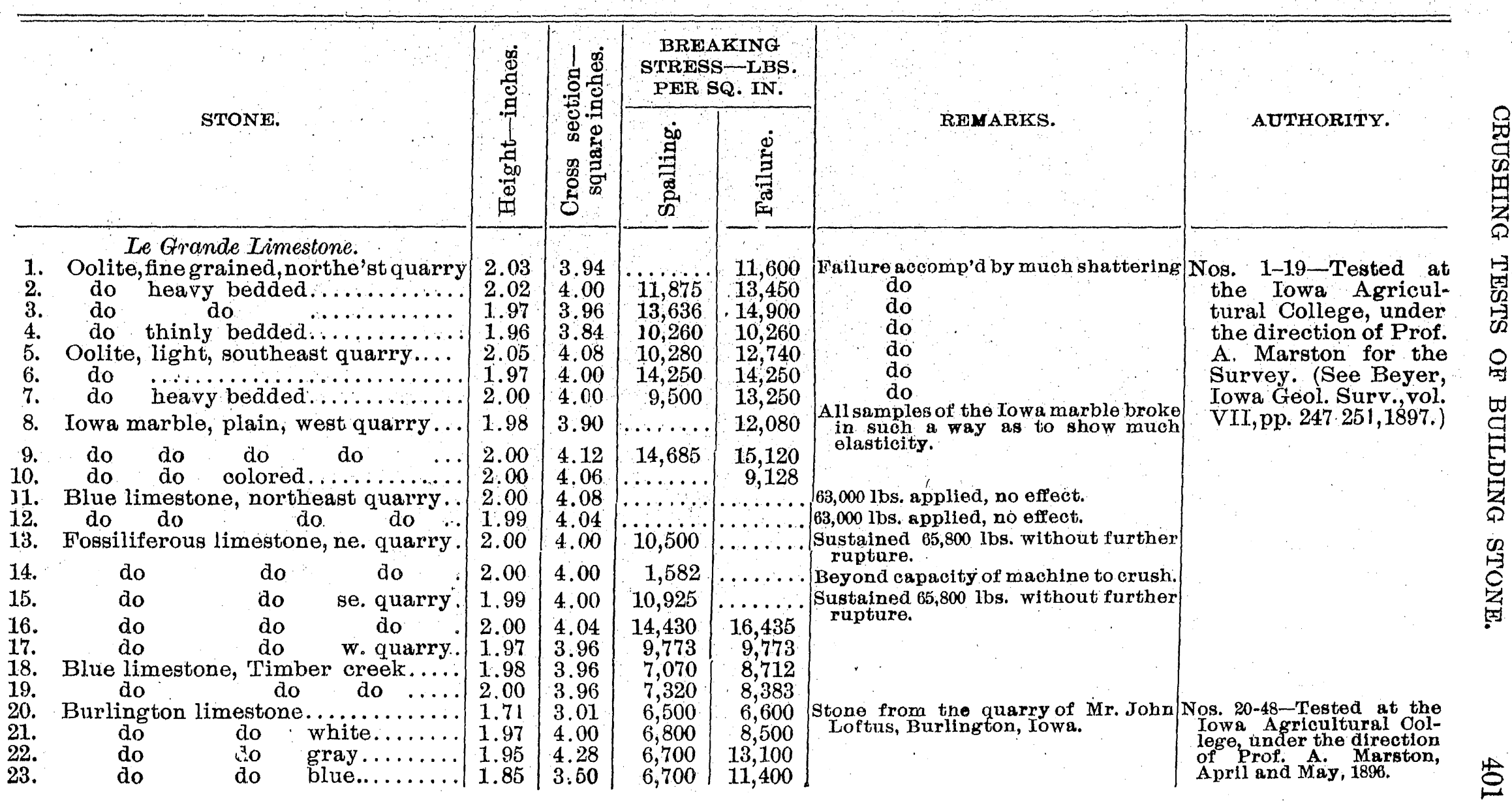


TABLE III-CONIINUED.

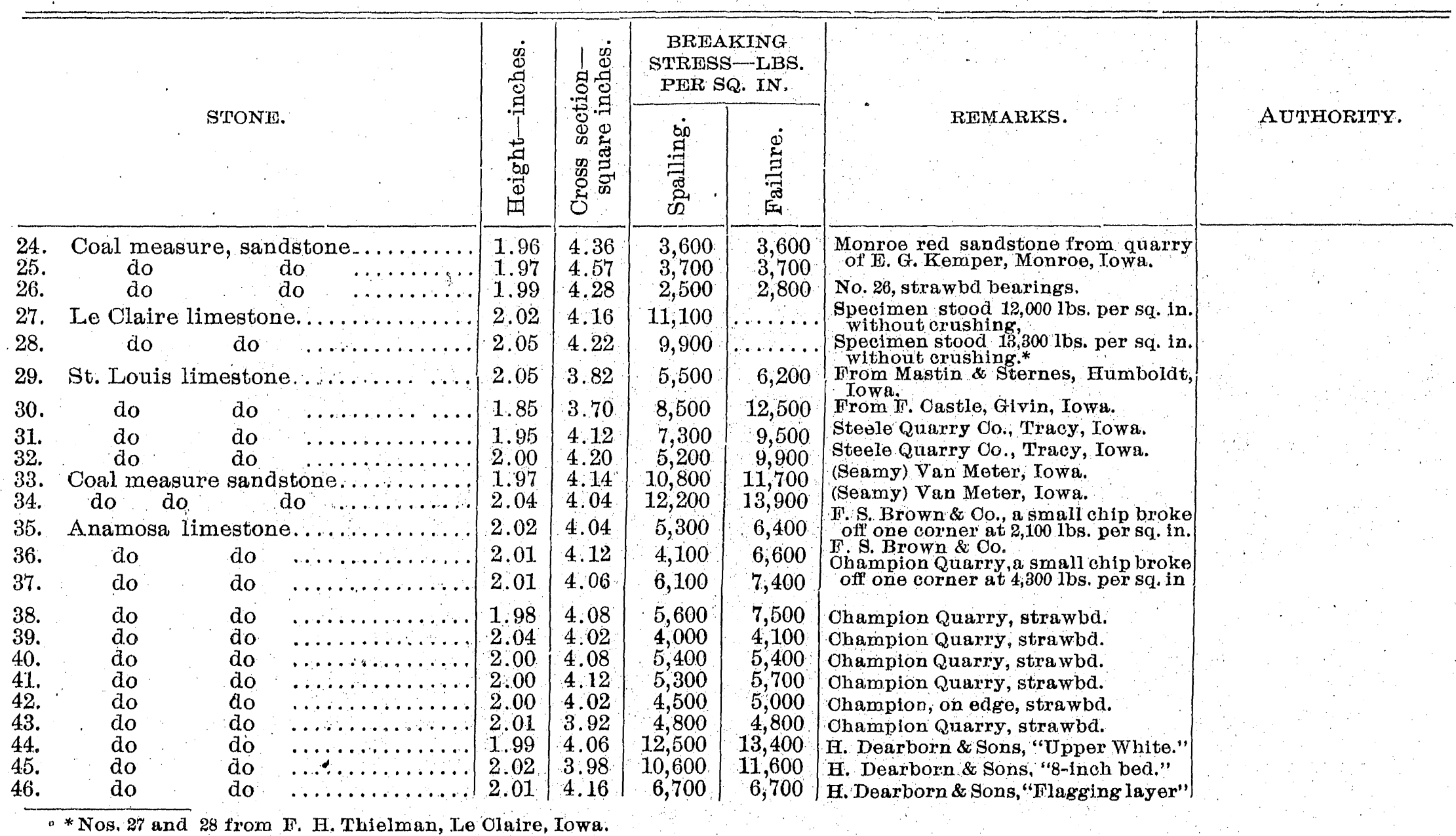




\begin{tabular}{|c|c|c|c|c|c|c|c|}
\hline $\begin{array}{l}47 . \\
48 . \\
49 .\end{array}$ & 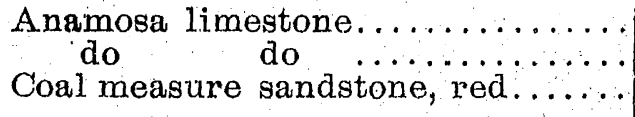 & $\begin{array}{l}1.98 \\
2.01\end{array}$ & $\begin{array}{l}4.10 \\
4.20\end{array}$ & $\begin{array}{r}12,200 \\
6,500 \\
6\end{array}$ & $\begin{array}{r}13,200 \\
6,500 \\
4,434\end{array}$ & 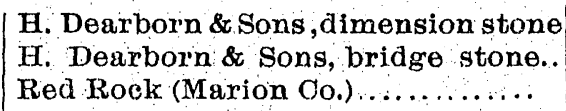 & L.Hi \\
\hline $\begin{array}{l}50 . \\
51 .\end{array}$ & $\begin{array}{l}\text { Marshalltown, oolite.. } \\
\text { Anamosa limestone... }\end{array}$ & & & & $\begin{array}{r}13,200 \\
7,625\end{array}$ & $\begin{array}{l}\text { Results furnished by the company. } \\
\text { Ohampion Quarry furnished by } \mathrm{J} \text {. }\end{array}$ & Howe, Rose Polytechnic. \\
\hline 52. & do do . & & & & 5,917 & $\begin{array}{l}\text { A. Green. } \\
\text { Stone olty quarries furnished by } \\
\text { Dearborn \&ons }\end{array}$ & Lieut. W. P. Butler. \\
\hline $\begin{array}{l}53 . \\
54 .\end{array}$ & $\begin{array}{l}\text { Winterset limestone (Bethany) } \\
\text { Anamosa limestione on bed..... }\end{array}$ & & & & $\begin{array}{r}4,588 \\
11.250\end{array}$ & Bevington Quarry $\ldots \ldots$ & Rock Island arsenal. \\
\hline 55. & do do on edge, & & & & 6,750 & Onampion Qu & $\begin{array}{l}\text { Dodge, Minn., Geol, Nat. } \\
\text { Hist. Surv., vol. I, p. } 200 . \\
\text { do }\end{array}$ \\
\hline $\begin{array}{l}56 . \\
57 .\end{array}$ & $\begin{array}{l}\text { Dolomite, Joliet, Ill . . . . . . } \\
\text { Limestone, Lemont, Iil . . . }\end{array}$ & & & & $\begin{array}{l}14,775 \\
12,000\end{array}$ & & Gillmore. \\
\hline & 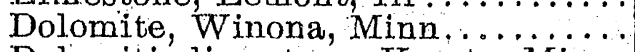 & & & & 16,250 & $\because$ & Winchell. \\
\hline & Dolomitic limestone, Kasota, Minn & & & & 18,500 & & Winc \\
\hline $\begin{array}{l}60 . \\
61 .\end{array}$ & $\begin{array}{l}\text { Sandstone, Portland, Conn. } \\
\text { Sandistone, Berea, Ohio.... }\end{array}$ & & & & $\begin{array}{l}4,945 \\
8,222\end{array}$ & & $\begin{array}{l}\text { Gillmore. } \\
\text { Gillmore. }\end{array}$ \\
\hline 62 & Oolite, Bedford, Ind...... & & & & 5,600 & A verage 3 specimens... & $\begin{array}{l}\text { Hopkins, Ind. Geol. Surv. } \\
\text { 1896, p. } 315 \text {. }\end{array}$ \\
\hline $\begin{array}{l}63 . \\
64 .\end{array}$ & $\begin{array}{l}\text { Quartzite, Pipestone, Minn........ } \\
\text { Granite, Vinalhaven, Me........ }\end{array}$ & $\ldots$ & & $\ldots \ldots \ldots$ & $\begin{array}{l}27,750 \\
15,698 \\
\end{array}$ & 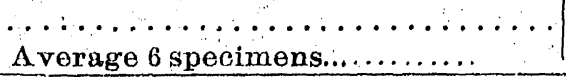 & $\begin{array}{l}\text { Gillmore. } \\
\text { Gillmore. }\end{array}$ \\
\hline
\end{tabular}

Hi Dearborn \& Sons, dimension ston

Results furnishod by tho company Oham Quarry furnished by tone Olty quarries furnished b

8,500

, 945

5,600 
The Le Grand stone is often known as the Marshalltown stone, since the quarries are both south and east of the latter place. It and the Anamosa stones probably have a wider sale than any other Iowa stones. The Joliet, Lemont, Kasota and Winona stones are the nearest competitors of the Iowa product. The Portland sandstone, No. 60 , is representative of the eastern brownstones, and may be compared with the Red Rock and Monroe stones. The Berea stone has been used to some extent in Iowa, but does not give good satisfaction here. The Bedford stone is quite extensively sold in Iowa. The quartzite is of the same character as that occasionally quarried in Lyon county. In selecting the foreign stones for comparison, the attempt has been made to take the stones which reach our market, and so far as possible, to get fair tests.

\section{Tests of Durability.}

As has been suggested, there is no single test which may be applied to a stone to determine its durability. There are a number of special tests designed to determine the resistance of stone to certain disintegrating influences, but the value to be attached to these tests is in dispute. It is also true that there are no fixed standards to be observed in their application. In each test there is a large variation in results, due to the method of the operator. It has been suggested that the crushing strength per square inch varies with the size of the specimen tested, position in the machine, nature of bearing surfaces and method of dressing the cube. In the same way, the manipulation of freezing and absorption tests may be'varied so as to produce diverse results in identical stone. In the end there are no absolute standards for comparison, and the best that can be done is to compare the results with those obtained by testing certain stones known to be good. Such comparisons are difficult and usually small value, since the difference in results due to difference in the methods of various engineers is often greater than the true difference 
between the stones compared. Until, however, a thorough system of tests be formulated, the method suggested is the best at hand.

Durability tests are usually intended to discover the resistance of the stone to certain mechanical and chemical effects. The more usual tests include absorption, freezing, chemical analysis and microscopic examinations. The ratio of absorption is, to some extent, indicative of the power of the stone to resist the mechanical action of frost, since the latter is manifestly due largely to the amount of water in the stone at the time of freezing. It also affords an index to the various chemical actions of solution, oxidation, etc., since the chemical elements which produce these changes are mainly carried into the stone by the water absorbed. It is a simple test, easily applied, and seems likely to be developed into something of real value.

Freezing tests are either natural or artificial. In the former the stones are alternately frozen and thawed, usually in cold storage rooms, at a rate and at temperatures which suit the convenience and fancy of the operator. In the artificial test the stone is saturated with a boiling solution of some soluble salt and then hung up to dry. The crystallization of the absorbed salt produces stresses more or less similar to those induced by frost action. The methods and value of freezing tests have been discussed by Luquer* who gives a brief bibliography of the subject. His paper is followed by an interesting discussion by Owen, Gerber, Phillips and others.

Chemical analyses are directed to the end of discovering the composition of the rock. By their means it should be possible to discover whether or not the constituents are readily soluble, subject to easy oxidation, carbonization or other changes to which the stone is apt to be exposed. A chemical analysis does not, however, always show the form in which the elements are combined, and this is often of supreme importance. From the analysis alone it is not always pos-

*Trans. Amer. Soc. O. E., vol. XXXIII, pp. 234-247. 
sible to tell just what variety or varieties of feldspar are present in a rock, and yet certain feldspars weather much more easily than others. Again, pyrites is usually a very undesirable constituent in light-colored limestones, and yet in certain cases may be present in considerable quantity without injuring the latter. For example, it may be disseminated through the densest portions only, and so may be protected from oxidation by the surrounding impervious material. To discover such facts, as well as to learn the state of aggregation, the character of the cement, the presence of interval stresses due to gas bubbles in the minerals (an important fac tor in resistance of the stone to heat) and similar points, a microscopic examination is useful. So far microscopic tests have been applied mainly to crystalline rocks. The methods do not seem so well adapted to the study of clastics for the reason that in the latter the bond material, which is the portion concerning which it is most desirable to have information, is usually amorphous. So far most of the microscopic tests are applicable only to crystalline bodies. It remains to be seen whether new tests can be devised to meet these conditions, and in the meantime microscopic examinations of the common clastic building stones is of doubtful utility.

In the tables below (Tables iv-vi) the results of such durability tests as have been made on Iowa stones are given. For comparison similar results upon well known building stones outside this state are quoted. 
TABLE IV.

FREEZING TESTS ON MARSHALITOW'N STONE.

\begin{tabular}{|c|c|c|c|c|c|c|c|c|c|c|}
\hline \multirow[b]{2}{*}{ 离 } & \multirow[b]{2}{*}{ KIND OW STONW. } & \multirow{2}{*}{ 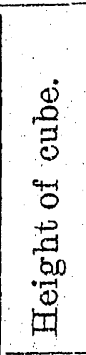 } & \multirow{2}{*}{ 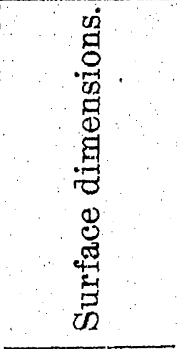 } & \multirow[b]{2}{*}{ 离 } & \multicolumn{2}{|c|}{$\begin{array}{l}\text { BRIEAKING } \\
\text { LOAD IN LBS }\end{array}$} & \multicolumn{2}{|c|}{$\begin{array}{l}\text { LOAD PER } \\
\text { SQUARE INOH. }\end{array}$} & \multirow{2}{*}{ 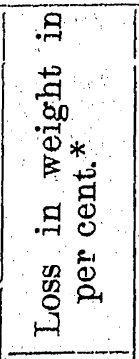 } & \multirow[b]{2}{*}{ REMARKS. } \\
\hline & & & & & 票 & 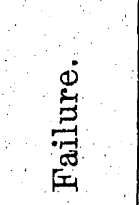 & م. & $\underset{\substack{D \\
:}}{\infty}$ & & \\
\hline $\begin{array}{l}1 \\
1\end{array}$ & $\begin{array}{c}\text { Oolite, fine-grained, northeast quarry } \\
\text { do } \ldots \ldots \ldots \ldots \ldots \ldots \ldots \ldots \ldots \ldots\end{array}$ & $\begin{array}{l}2.05 \\
2.08\end{array}$ & $\begin{array}{l}2.00 \times 2.08 \\
2.00 \times 2.08\end{array}$ & $\begin{array}{l}4.16 \\
4.16\end{array}$ & $\begin{array}{l}55,700 \\
26,000\end{array}$ & $\begin{array}{l}56,400 \\
\cdots \cdots\end{array}$ & $\begin{array}{r}13,390 \\
6,250\end{array}$ & $\begin{array}{l}13,558 \\
14,280\end{array}$ & $\begin{array}{l}0.0014 \\
0.0013\end{array}$ & $\begin{array}{l}\text { Loud report. } \\
\text { Sustained } 59,4001 \mathrm{bs} . \text { Very } \\
\text { slight spall at } 26,000 \text { lbs. }\end{array}$ \\
\hline 5 & Oolite, fine-grained, southesist quarry & 1.99 & $1.97 \times 2.00$ & 3.94 & 50,000 & 60,000 & 12,690 & 15,230 & & $\begin{array}{l}\text { Toud report, cube much } \\
\text { shattered. }\end{array}$ \\
\hline $\begin{array}{r}5 \\
5 \\
8 \\
8 \\
8 \\
11\end{array}$ & 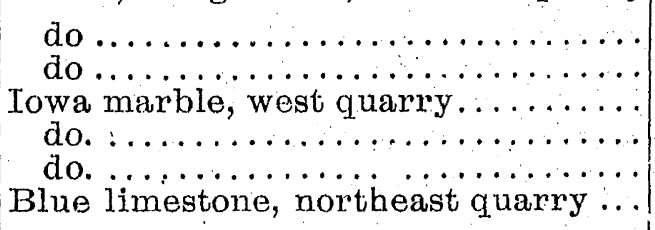 & $\begin{array}{l}2.00 \\
2.02 \\
1.96 \\
1.92 \\
2.00 \\
2.00\end{array}$ & $\begin{array}{l}2.00 \times 1.96 \\
1.97 \times 1.97 \\
3.02 \times 2.02 \\
2.00 \times 2.00 \\
2.04 \times 2.02 \\
1.98 \times 1.97\end{array}$ & $\begin{array}{l}3.92 \\
3.88 \\
4.08 \\
4.00 \\
412 \\
3.90\end{array}$ & $\begin{array}{l}34,000 \\
50,000 \\
50,000 \\
42,600 \\
38,000 \\
\cdots\end{array}$ & $\begin{array}{l}55,700 \\
56,500 \\
56,500 \\
52,700 \\
51,700\end{array}$ & $\begin{array}{r}8,673 \\
12,890 \\
12,255 \\
10,650 \\
9,225\end{array}$ & $\begin{array}{l}14,210 \\
14,560 \\
13,850 \\
13,175 \\
12,550 \\
15,360+\end{array}$ & $\begin{array}{l}0.0007 \\
0.0008 \\
0.0009\end{array}$ & $\begin{array}{l}\text { do } \\
\text { do } \\
\text { Broke with a loud report. } \\
\text { do } \\
\text { do } \\
59,400 \text { lbs applied without } \\
\text { effect. }\end{array}$ \\
\hline 13 & Fossiliferous limestone, nor theast qr. & 2.00 & $2.00 \times 2.02$ & 4.08 & & & & $14,560+$ & & $\begin{array}{l}\text { eftect. } \\
\text { ef,400 lbs. applied without } \\
\text { effect. }\end{array}$ \\
\hline $\begin{array}{l}13 \\
17 \\
17 \\
18 \\
18\end{array}$ & 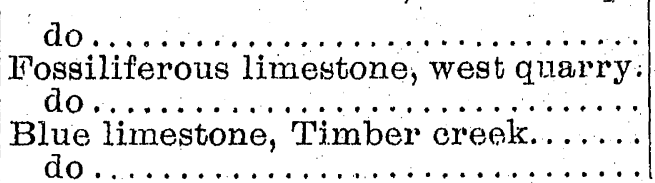 & $\begin{array}{l}1.98 \\
1.98 \\
1.97 \\
2.00 \\
1.96\end{array}$ & $\begin{array}{l}1.97 \times 2.00 \\
2.04 \times 2.02 \\
1.99 \times 1.96 \\
2.04 \times 2.01 \\
1.98 \times 1.96\end{array}$ & $\begin{array}{l}3.94 \\
4.12 \\
3.91 \\
4.10 \\
3.88\end{array}$ & $\begin{array}{l}55,600 \\
35,900 \\
30,500 \\
28,000 \\
32,700\end{array}$ & $\begin{array}{l}40,000 \\
35,000 \\
36,300 \\
32,700\end{array}$ & $\begin{array}{r}14,035 \\
8,715 \\
7,800 \\
6,830\end{array}$ & $\begin{array}{c}14,900+ \\
9,710 \\
8,950 \\
8,850 \\
8,430\end{array}$ & & $\begin{array}{l}59,400 \text { llss: sustained. } \\
\text { Weak report. } \\
\text { do } \\
\text { Slight report. }\end{array}$ \\
\hline
\end{tabular}

*The cutes with distilled water and placed in wooden trays, eight by eight inches and two inches deep provided with wire bottoms. The trays alter being securely packed were placed in the refrigerator and liept, at a temperature of hom 1. This process was repeated six times. The specimens were rofterwards subjected to refrigeratlon and thawing ten times, but the conditions were less constant than in the first six. In the latter series the minimum temperature ranged from $21^{\circ}$ to $32^{\circ}$ F. F. trihe above table shows that the blocks suffered no appreciable loss in were that lower temperature would wave of the apparent weakness. low specific gravity and rathe 
The results given in Table IV were obtained at the Iowa Agricultural college under the direction of Prof. A. Marston, the work being done by Messrs. G. W. Zorn and J. W. Elliott. They are a portion of a complete series of tests of the Marshalltown stone* made to some extent with a view of testing the tests. It will be noted that the Blue limestone, which is known to be very durable, stood the tests very poorly. It is easy to correlate the high absorption, low specific gravity and loss by freezing, as they manifestly indicate a stone of relatively open texture. In the chemical analysis the same thing is perhaps indicated by the slightly larger amount of water contained (Table VII). Despite the open texture, however, the stone stands well and is of good quality so that, in this case at least, the results of the tests are misleading.

The results given in Table $V$ are from the same series of tests. Those given in Table VI were obtained by Mr. H. B. Murray at Drake university. The same stones were crushed at Ames, under the direction of Professor Marston, by $\mathbf{M r}$. Murray and the author, and the results are given in Table III under corresponding numbers. A few absorption tests from various sources are added.

*Beyer: Iowa Geol. Surv, vol. VII, pp. 242-25l. 189r. 
TABLE $V$

ABSORPTION AND SPECIFIC GRAVITY TESTS OF MARSHALTIOWN STONE.

\begin{tabular}{|c|c|c|c|c|c|c|c|c|c|c|c|}
\hline \multirow[b]{2}{*}{ 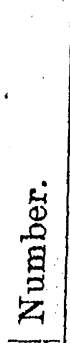 } & \multirow{2}{*}{ NAME OF STONE-MARSHALLTOWN. } & \multicolumn{3}{|c|}{$\begin{array}{l}\text { LOSS OF QUARRY } \\
\text { WATER THROUGH } \\
\text { DRYING-WT IN GS. }\end{array}$} & \multicolumn{4}{|c|}{$\begin{array}{c}\text { WATER ABSORBED AFTER } \\
\text { IMMERSION, EXPRESSED } \\
\text { IN PERCENTAGES, } \\
\text { OVER DRY WETGHTS. }\end{array}$} & \multirow{2}{*}{ 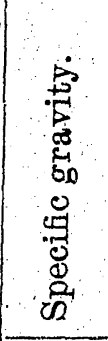 } & \multirow{2}{*}{ 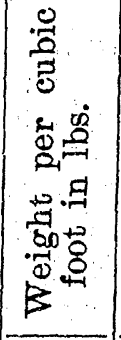 } & \multirow{2}{*}{ REMARKS. } \\
\hline & & 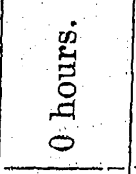 & $\stackrel{\dot{c}}{\check{c}}$ & $\stackrel{\dot{m}}{\mathscr{D}_{2}}$ & $\frac{\dot{a}}{5}$ & 象 & $\begin{array}{l}\dot{0} \\
\dot{2} \\
\dot{\Xi} \\
\dot{g} \\
\dot{N}\end{array}$ & $\frac{3}{3}$ & & & \\
\hline \multirow[t]{4}{*}{1} & Oolite, fine-grained, northeast quarry. & 350.90 & 350.70 & 350.58 & 0.85 . & 1.59 & 2.66 & 2.75 & & & \multirow{14}{*}{ Average. } \\
\hline & 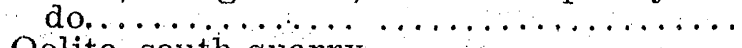 & 348.91 & 348.79 & 348.63 & 1.56 & 3.26 & 3.95 & 4.05 & 50,0 & 0 & \\
\hline & 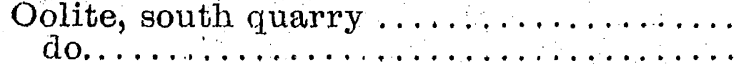 & 335.03 & 334.99 & 334.97 & 1.20 & 1.50 & 2.50 & 2.61 & 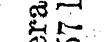 & 20 & \\
\hline & 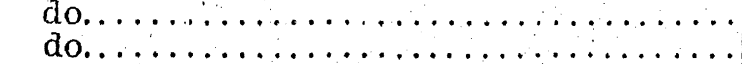 & 333.40 & 333.79 & 333.63. & 0.71 & 1.85 & 2.11 & 2.20 & & $\dot{8}$ & \\
\hline 8 & $\begin{array}{l}\text { do................... } \\
\text { Iowa marble; west quai }\end{array}$ & 326.90 & 326.30 & 325.63 & 1.50 & 1.96 & 2.55 & 2.64 & 40 & $\sqrt{-1}$ & \\
\hline 8 & $\begin{array}{l}\text { Iowa marble; west quat } \\
\text { do } \ldots \ldots \ldots \ldots \ldots \ldots \ldots\end{array}$ & 323.10 & 327.70 & 322.47 & 2.33 & 3.02 & 3.60 & 3.87 & 2.54 & 153.2 & \\
\hline 8 & $\begin{array}{l}\text { do } \ldots \ldots \\
\text { do....... }\end{array}$ & 309.40 & $\begin{array}{l}309.00 \\
370.00\end{array}$ & 308.01 & 1.81 & 2.43 & 3.31 & 3.57 & $\cdots$ & $\cdots$ & \\
\hline 11 & Blue limest & 348.70 & 348.21 & 348.19 & 0.48 & 0.86 & 1.86 & $\begin{array}{l}* .06 \\
2.02\end{array}$ & 2.77 & 173.0 & \\
\hline 13 & Fossiliferous limestone, northeast quarry. & 344.00 & 343.78 & 343.52 & 0.72 & 1.01 & 1.72 & 1.79 & 2.60 & 162.5 & \\
\hline 12 & & 353.86 & 353.40 & 353.20 & 0.22 & 0.50 & 0.70 & 0.77 & & & \\
\hline 17. & ous limestone, west quarry..... & 311.00 & 310.90 & 310.87 & 0.06 & 0.84 & 1.65 & 1.79 & & & \\
\hline 17 & do $\ldots \ldots \ldots \ldots \ldots \ldots \ldots$ & 340.91 & 340.46 & 340.38 & 0.22 & 0.84 & 1.64 & 1.79 & & & \\
\hline 18 & Blue limestone, Jimber creek. .... & 320.76 & 320.36 & 320.00 & 2.03 & 3.01. & 3.17 & 3.36 & 2.30 & 144.0 & \\
\hline 181 & do $\ldots \ldots \ldots \ldots \ldots \ldots \ldots \ldots$ & 285.741 & 285.36 & 285.15 & 4.00 & 4.67 & 5.41 & 5.651. & & & \\
\hline
\end{tabular}


TABLE VI.

ABSORPTION WESTS OF VARIOUS STONES.

\begin{tabular}{|c|c|c|c|c|c|c|c|}
\hline \multirow[b]{2}{*}{ 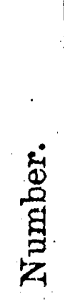 } & \multirow[b]{2}{*}{ STONE. } & \multicolumn{3}{|c|}{$\begin{array}{l}\text { PER OENT OF } \\
\text { INOREASE. }\end{array}$} & & $?$ & . \\
\hline & & 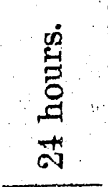 & $\frac{1}{0}$ & 覀 & QUARRY. & AUTHORITX: & REMARTS. \\
\hline 22. & Burlington gray & 1.10 & .77 & 1.87 & oftus, Burlington... & Murray. & \\
\hline 21 & do whit & .39 & .35 & .74 & do do & do & \\
\hline 24 & Coal measure sandst one & 6.90 & 1.74 & 8.64 & Kemper,Monroe, Ia & do & \\
\hline 27 & Le Claire limestone... & 3.11 & 1.21 & 4.32 & Le Claire, Iowa.... & do & \\
\hline 29 & St. Louis limestone.... & 3.09 & 1.22 & 4.31 & Mastin \& Sterns, Humboldt & do & \\
\hline 31 & do do $\ldots$ & 2.28 & .99 & 3.27 & Steel, Tracy, Iowa........ & do & A broken piece. \\
\hline 33 & Coal measure sandstone & 2.88 & 1.27 & 4.15 & Van Meter, Iowa... & do & \\
\hline$\cdots$ & Anamosa limestone.... & 5.66 & 1.82 & 7.48 & Champion, Stone City.... & $\ldots \ldots \ldots \ldots$ & Spalls from crushing machine. \\
\hline$\cdots$ & $\begin{array}{ll}\text { do } & \text { do } \\
\text { do } & \text { do }\end{array}$ & $\begin{array}{l}7.61 \\
4.94\end{array}$ & 1.76 & $\begin{array}{l}9.37 \\
6.91\end{array}$ & $\therefore \quad$ do $\quad \cdots$ & $\begin{array}{l}\text { do } \\
\text { do }\end{array}$ & Dresced anhe \\
\hline$\because$ & Coal measure sandstone & 8.71 & 211 & 10.82 & Red Rock, Dunreith....... & do & $\begin{array}{l}\text { Dressed oube. } \\
\text { Buff stone corresponds to No. } 49\end{array}$ \\
\hline$\cdots$ & do do & 8.00 & 2.82 & 10.82 & do do do. & do & do do \\
\hline .. & St. Louis limestone... & 2.71 & .63 & 3.34 & Oskaloosa $\ldots \ldots \ldots \ldots \ldots$ & & \\
\hline$\cdots$ & Granite. .............. & .11 & .19 & 30 & & & From drift bowlder. \\
\hline$\cdots$ & Anamosa limestone.... & 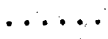 & $\cdots \cdots$ & 5.45 & Champion .............. & G.S. Morrison ...... & Length of test unknown \\
\hline$\cdots$ & Winterset do $\cdots$ & & $\cdots \cdots$ & 42 & Bevington $\ldots \ldots \ldots \ldots$ & Rock Island Arsenal. & do do do \\
\hline$\cdots$ & Dolomite, Joliet, Ill fil & & $\cdots \cdots$ & $\frac{9}{3}$ & $\cdots \cdots \cdots \cdots \cdots \cdots$ & $\ldots \ldots \ldots \ldots \ldots \ldots$ & Gillmore. \\
\hline$\cdots$ & Dolomite, Winona, Min. & $\cdots \ldots$ & $\cdots \cdots$ & $\frac{89}{21}$ & $\ldots \ldots \ldots \ldots \ldots \ldots$ & $\ldots \ldots \ldots$ & Winchell. \\
\hline .. & Dolomite,Kasota, Minn. & & & $\frac{1}{8}$ & $\cdots \cdots \cdots \cdots \cdots \cdots, \cdots \cdots \cdots$ & $\ldots \ldots \ldots \ldots \ldots \ldots$ & do \\
\hline$\cdots$ & 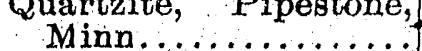 & & & $\frac{1}{3}$ & & & Gillmo 2 o 20 \\
\hline$\ldots$ & Sandstons, Berea, Ohio & & & $\mathbf{2}$ & $\cdots$ & $\ldots \cdots \cdots$ & do \\
\hline & Oolite, Bedford........ & & & $\frac{1}{2} 3$ & $\ldots \ldots \ldots \ldots \ldots \ldots \ldots \ldots \ldots$ & 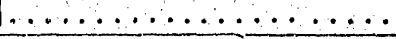 & Hopkins. \\
\hline
\end{tabular}


TABLE VII.

CHEMICAL ANALYSES OF MARSHALLTOWN STONE.

\begin{tabular}{|c|c|c|c|c|c|c|}
\hline CONSTITUंENTS, & 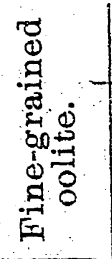 & 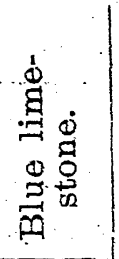 & 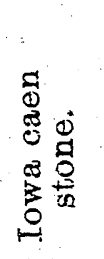 & 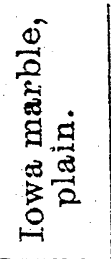 & 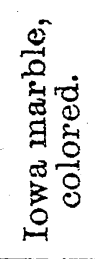 & 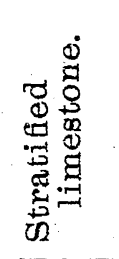 \\
\hline $\begin{array}{l}\mathrm{ygr} \\
\mathrm{omg}\end{array}$ & 0.03 & 0.09 & 0.06 & 0.04 & 0.06 & 0.04 \\
\hline & 0.13 & 0.21 & 0.15 & 0.19 & 0.12 & 0.12 \\
\hline lic & & & & & & \\
\hline id, & 43. & 43.3 & 43. & 44.8 & 44.7 & 43.85 \\
\hline$A \geq$ & 0. & 0. & & & & 0.14 \\
\hline $0^{\circ}$ & No & None & & & & 0.2 \\
\hline & 0 & 0.27 & 0. & 0 . & 0. & 0.09 \\
\hline & 55.05 & 54.85 & 50.5 & 45.42 & 45. & 50.42 \\
\hline & 0.28 & 0.28 & 3.70 & 8.21 & 8.28 & 3.96 \\
\hline $\mathrm{Oc} 9 \mathrm{Mn} \mathrm{O}$ & & 0.08 & & & & Trace \\
\hline Phospho & & & Trace & Trace & & \\
\hline Totals. & 100.02 & 100.11 & 99.92 & 99.99 & 100.06 & 100.10 \\
\hline
\end{tabular}

PROBABLE COMBINATIONS.

\begin{tabular}{|c|c|c|c|c|c|c|}
\hline Water & 0.16 & 0.30 & 0.21 & 0.23 & 0.18 & 0.16 \\
\hline Calcium carbonate, $\mathrm{Ca} \mathrm{Co}$ & 98.30 & 97.95 & 90.28 & 81.11 & 81.05 & 90.04 \\
\hline Magnesium carbonate, $\mathrm{Mg} \mathrm{Co}_{2}$ & 0.59 & 0.38 & 7.77 & 17.24 & 17.39 & 8.08 \\
\hline $\left.\begin{array}{l}\text { Silica and silicates...... } \\
\text { Alumina, iron, oxide, etc. }\end{array}\right\} \ldots$ & 0.95 & 1.37 & 1.74 & 1.42 & 1.38 & 1.72 \\
\hline$\therefore$ & 0.00 & 0.00 & 0.00 & 100.00 & 00.00 & 00.00 \\
\hline
\end{tabular}

The analyses given above were made in the Survey laboratory, by Prof. G. E. Patrick. Those quoted below were made at Drake university, by Prof. Harry McCormick. They are followed by miscellaneous analyses from various sources. 
TABLE VIII.

CHEMTCAI ANATYSES OF VARIOUS STONES.

\begin{tabular}{|c|c|c|c|c|c|c|c|c|c|c|c|c|}
\hline STONE. & $\delta_{0}^{\infty}$ & $\begin{array}{l}0 \\
\therefore \\
0\end{array}$ & $\begin{array}{l}8 \\
0 \\
20\end{array}$ & $\sum_{j}^{0}$ & $\begin{array}{l}\dot{0} \\
\dot{0}\end{array}$ & $\tilde{0}^{\dot{m}}$ & $\begin{array}{l}0 \\
0 \\
+ \\
0 \\
0 \\
0 \\
\text { En }\end{array}$ & $\ddot{\mathscr{\theta}}$ & 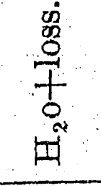 & 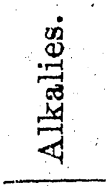 & CHEMIST. & AUTHORITY. \\
\hline $\begin{array}{l}\text { St. Louis limestone, Oskaloosa } \\
\text { St. Louis limestone, Humboldt }\end{array}$ & $\begin{array}{l}95.30 \\
97.98\end{array}$ & & & $\cdots$ & $\because \cdots \cdots$ & $\begin{array}{l}13 \\
48\end{array}$ & $\begin{array}{l}.46 \\
.73\end{array}$ & $\begin{array}{r}4.01 \\
.91\end{array}$ & & $\ldots \cdots$ & Murray. & \\
\hline 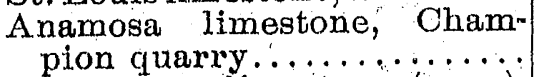 & 55.17 & $\therefore$ & 42.79 & & & .19 & .42 & .1 .43 & & & do & \\
\hline Burlington limestone (gray), & 9361 & & & & & .87 & 1.27 & 4.25 & & & do & \\
\hline $\begin{array}{l}\text { Coal measure sandstone, Mon- } \\
\text { roe } \ldots \ldots\end{array}$ & & .88 & & 3.17 & $\begin{array}{l}84.35 \\
\therefore \ldots\end{array}$ & $\begin{array}{r}8.62 \\
.49\end{array}$ & $\begin{array}{r}5.59 \\
.17\end{array}$ & 1.57 & .43 & $\cdots \cdot \cdot \quad \square \quad \square$ & $\begin{array}{l}\text { do } \\
\text { do }\end{array}$ & \\
\hline $\begin{array}{l}\text { St. Louis limestone, Tracy } \\
\text { Coal measure 'sandstone, Van }\end{array}$ & 94.60 & $\cdots \cdots$ & $\because \ldots \ldots$ & 3.17 & $\cdots \cdot$ & & & & & & & \\
\hline Le Claire limestone, Le Claire & 57.54 & 4.95 & 41.57 & $\begin{array}{l}3.19 \\
\ldots \ldots\end{array}$ & $\begin{array}{l}84: 27 \\
\ldots \ldots\end{array}$ & $\begin{array}{l}.62 \\
.26\end{array}$ & $\begin{array}{r}4.74 \\
.23\end{array}$ & $\because 46$ & 2.07 & & $\begin{array}{l}\text { do } \\
\text { do }\end{array}$ & \\
\hline $\begin{array}{l}\text { Coal measure sandstone (ned), } \\
\text { Dunreith ...................... }\end{array}$ & & $\operatorname{Tr}$ & $\ldots \ldots$ & & 94.02 & 1.76 & 2.65 & & 1.39 & & do & \\
\hline $\begin{array}{l}\text { Coal measure sandstone (buff), } \\
\text { Dunreith } \ldots \ldots \ldots \ldots \ldots \ldots\end{array}$ & & .41 & & & 94.40 & 3.03 & .94 & & 1.09 & & do & \\
\hline $\begin{array}{l}\text { Kinderhook magnesian, Mar } \\
\text { shalltown } \ldots \ldots \ldots \ldots \ldots \ldots\end{array}$ & 74.10 & & 23.35 & & .95 & & & & .40 & & C.G.A. Mariner & $\left\{\begin{array}{l}\text { Le Grand } \\
\text { Quarry Oo. }\end{array}\right.$ \\
\hline Sandstone, Berea, Obio....... & $\ldots \ldots$ & .74 & $\therefore \cdots$ & 2.11 & 44.40 & 7.49 & 3.87 & & & .90 & & Winchen. \\
\hline $\begin{array}{l}\text { Dolomitic limestone, Kasota, } \\
\text { Minn }\end{array}$ & $\begin{array}{l}47.90 \\
98.30\end{array}$ & $\ldots \ldots$ & 35.20 & & & .84 & $\begin{array}{r}1.49 \\
.15\end{array}$ & $\begin{array}{r}13.85 \\
.64\end{array}$ & $\begin{array}{ll}. .31 \\
\ldots \ldots\end{array}$ & & & do \\
\hline
\end{tabular}




\section{Microscopical Examinations.}

But few of the Iowa building stones have been studied under the microscope. The difficulties in the way of the accurate determination of the minerals in unalterated sedimentary rocks are so great as to be discouraging. The particles are small, the material is largely amorphous, and many of the important minerals, calcite, dolomite, limonite, etc., are those which are not of much importance in crystalline rocks. As the latter have attracted the major attention of petrographers, the criteria for the recognition of certain of the minerals named are quite imperfect. In addition the particles under investigation are in most cases impure. For these reasons the microscope has never been the aid in the study of sedimentary rocks that it has in the crystallines. This is unfortunate, since so large a number of the building stones belong to the sedimentary series, and the range of information yielded by the microscope is, in most cases, peculiarly valuable in the study of building stones. The investigation of thin sections should allow the ready determination of the constituents of the stone, which may also indeed be learned by means of a chemical analysis. Microscopic examinations should, however, in addition show the form of combination and the freshness of the materials; both facts of special interest in estimating the durability of the stone. Something as to the state of aggregation, presence or absence of internal stresses and of fine cracks, the nature of the matrix and the hardness of the rock, may all be learned, as has been suggested, in the course of a microscopic study.

No such thorough investigation of Iowa building stones has been yet attempted. A few of the typical and better known rocks have been sectioned, and micro-photographs are shown in plates xl-xlii. The stones examined were those of which chemical analyses were made, and which were also crushed. By comparing the results in the various tables, the value of the stone as indicated by the tests may be estimated. Below

38 G Rep. 
is a brief description of the appearance of the stones under the microscope.

Monroe Red Sandstone (x45) (Fig. 1, pl. xxx). Matrix, ferruginous matter apparently including both hematite and limonite, with a little earthy material. The clear white particles are quartz; a few being rounded and water-worn, but most of the pieces having sharp fracture edges. There are no signs of internal stress, such as would be indicated by undulatory extinction.

Tan Meter Sandstone (x45) (Fig. 2, pl. xxx). The rock consists mainly of small, sharp-cornered bits of quartz fitted close together, and with a sparing matrix of calcite and ferruginous material. The calcite is occasionally stained and clouded by ferruginous matter, in colors from green to brown.

Burlington Limestone (x45) (Fig. 1, pl. xxxi). The large striated crystals are calcite, showing the usual cleavage lines. There is no matrix, as the material has been wholly re-crystallized and is now a coarse marble. It is of the type called here sub-crystalline. No impurities are shown.

Burlington Limestone ( $x 38)$ (Fig. 2, pl. xxxi). A different portion of the same section with smaller magnification.

Anamosa Limestone (x80) (Fig. 1, pl. xxxii). The section is eut across the bedding planes and shows the small sharp-cornered bits of dolomite, and the alternate compact and open structure which corresponds to the latter. The rock shows occasional bits of iron-stained material, a few being indicated in the photo.

Anamosa Limestone (x80) (Fig. 2, pl. xxxii). Section cut parallel to bedding showing the uniform size and regular distribution of the dolomitic grains. It will be noted, that the texture is the same along this plane, though varying from plane to plane as shown in the previous section. . The grains are sharp-cornered and little worn, but their relations to bedding planes indicate that the rock was deposited as a dolomite. 


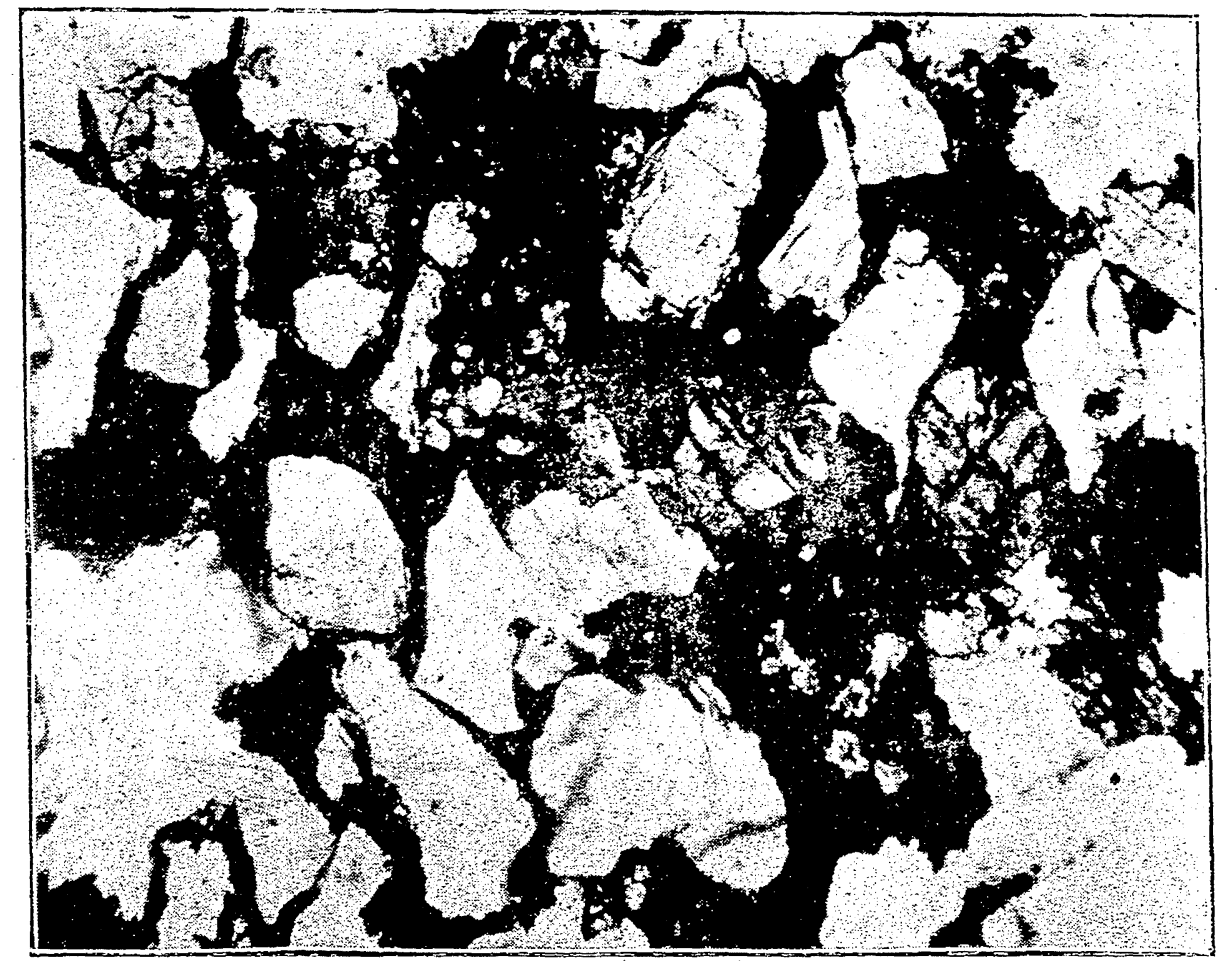

FIG. 1. Microphotograph ( $\mathrm{x} 45$ ), Monroe red sandstone, natural light.

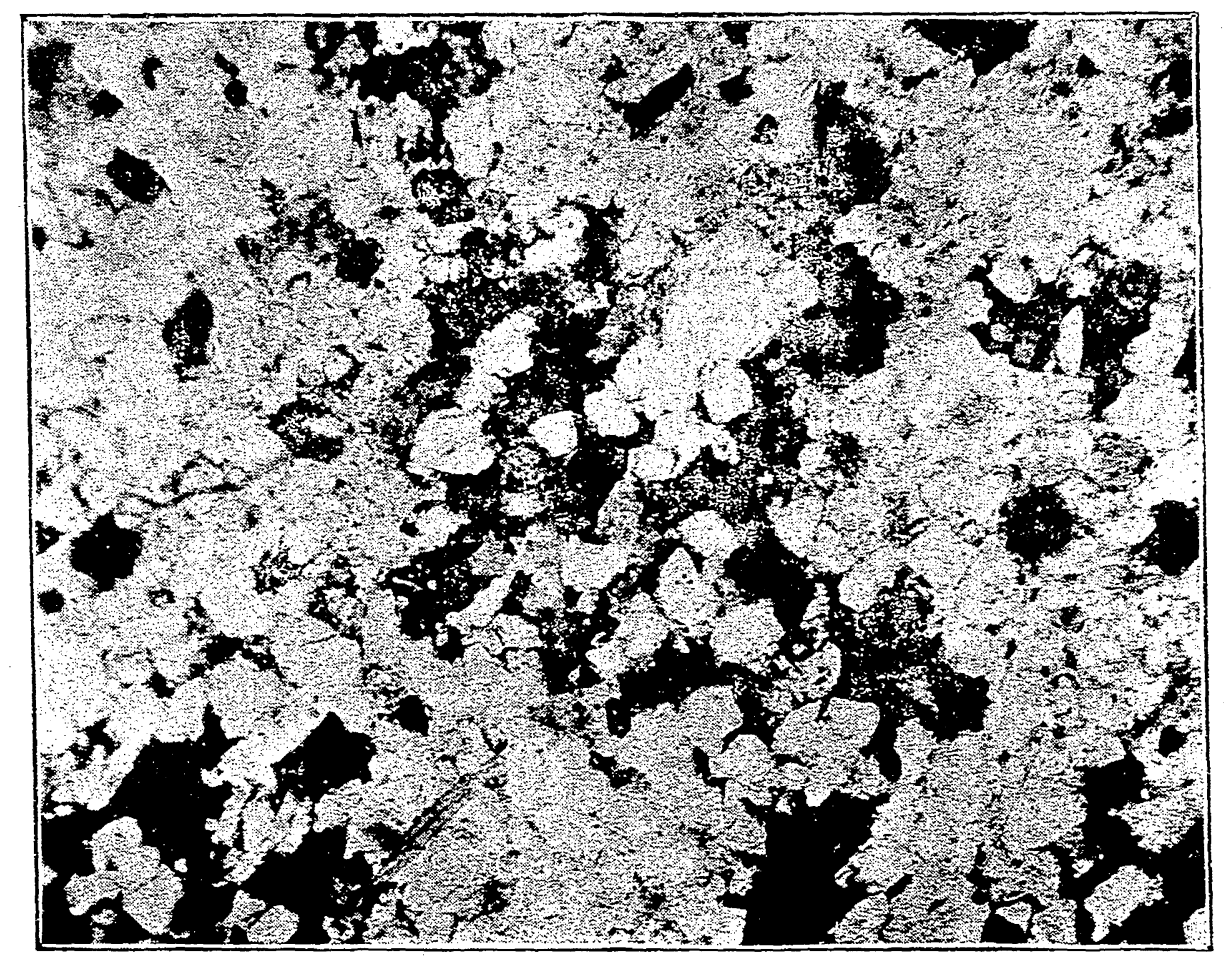

FIG. 2. Microphotograph (x 45), Van Meter sand̄stone, natural light. 



\section{GENERAL CONCLUSIONS.}

The results of the various tests so far made on Iowa building stones, indicate that the latter do not suffer by comparison with stones of the same class from elsewhere. These results have been amply confirmed by practice in the case of the stones now on the market. In the end the latter must prove the final arbiter. In the present confused condition of affairs the value to be assigned to most of the tests and the utility of many of them may be well doubted. The appearance of the stone in the quarry, so long as it is used under essentially similar climatic conditions as would be true anywhere in Iowa or neighboring states, is probably a more important guide than any series of tests yet formulated.

Below is a summary of the quarry production for 1897 taken from the tables published elsewhere in this volume. The sandstones have not been separated from the limestone, as they form a very inconsiderable portion of the output. The sandstone output usually credited to Iowa is made up largely of dolomite, which is frequently classed in the local markets as sandstone.

Production for $189 \%$.

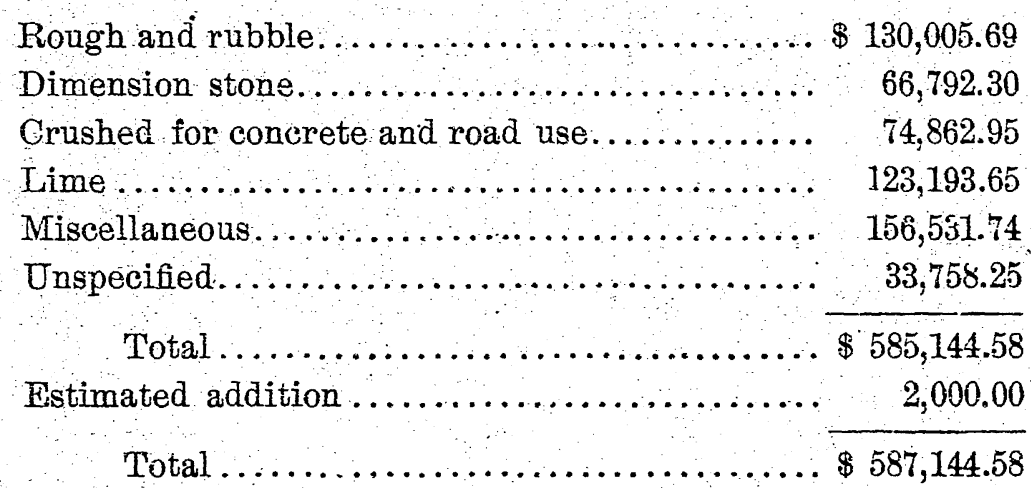

The stones now marketed are mainly dolomites and limestones belonging to the Silurian and Devonian. The Mar- shalltown and Burlington stones are the most important representatives of the Carboniferous. Above the Augusta 
good stone is rare. The sandstones of the Des Moines will probably in time become important sources of quarry products, but for the present they attract but little attention. The Cretaceous yields nothing of more than local importance to the building trade. The use of gypsum as a building stone at Fort Dodge is now uncommon, and the sandstones found lower in the formation are rarely quarried. The great bulk of the quarry products of the state come from the Cedar Valley limestone of the Devonian and the various members of the Niagara. The Galena yields an important amount of stone, but the Oneota, which includes a buff dolomite second to none in quality, is, for lack of transportation facilities, shut out of the market. 



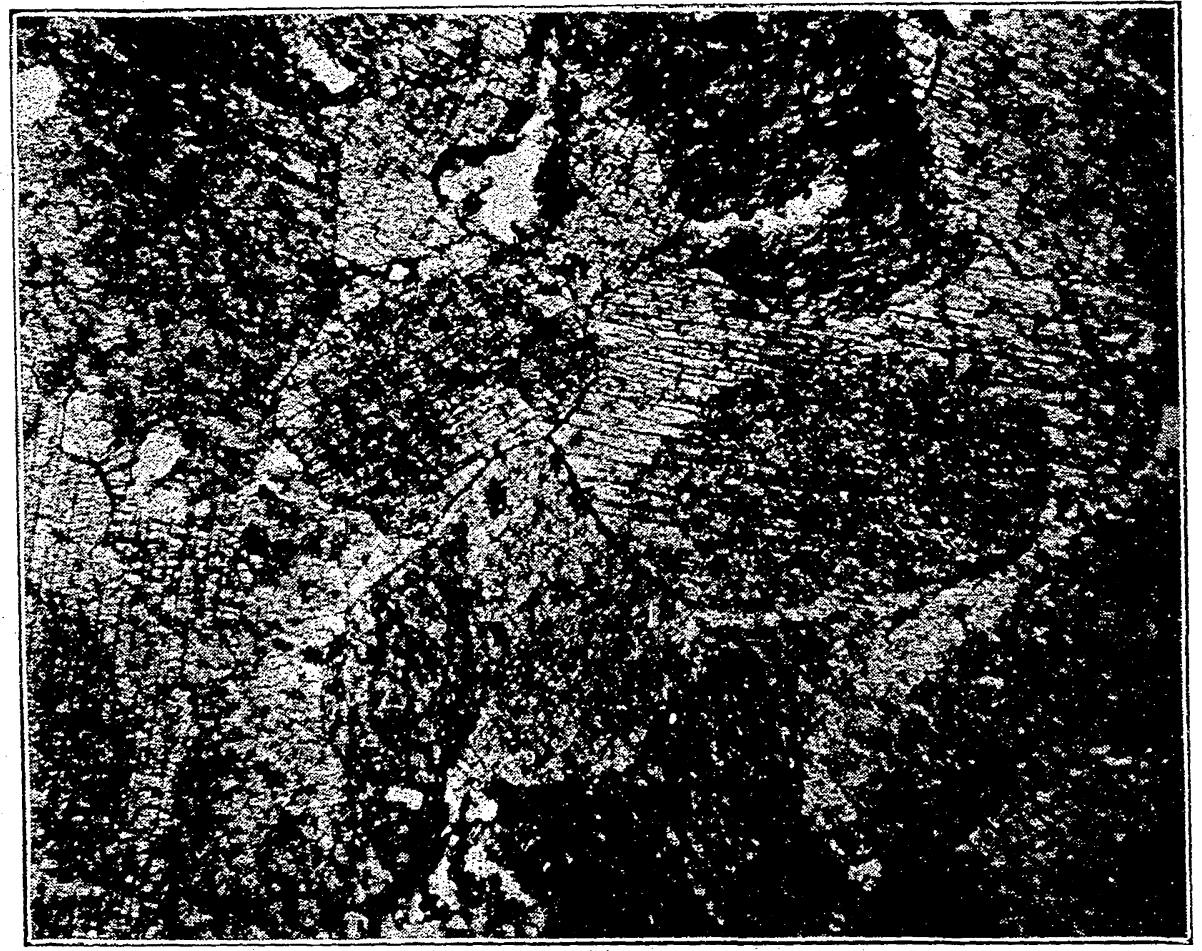

Fra.1 Microphotograph x 45), Burlington limestone, natural light.

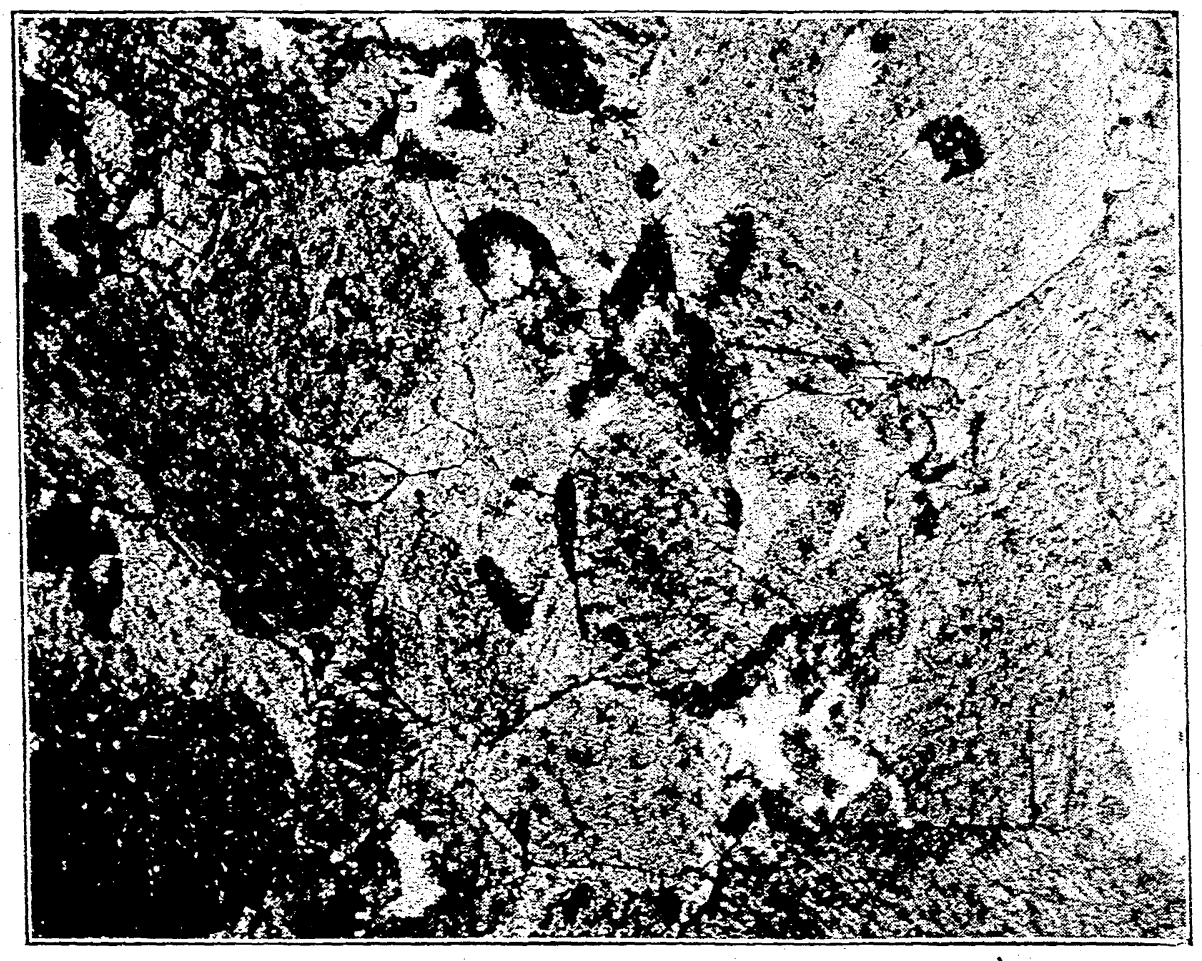

FIG. 2. Microphotograph $(x 38)$, Burlington limestone, natural light. 


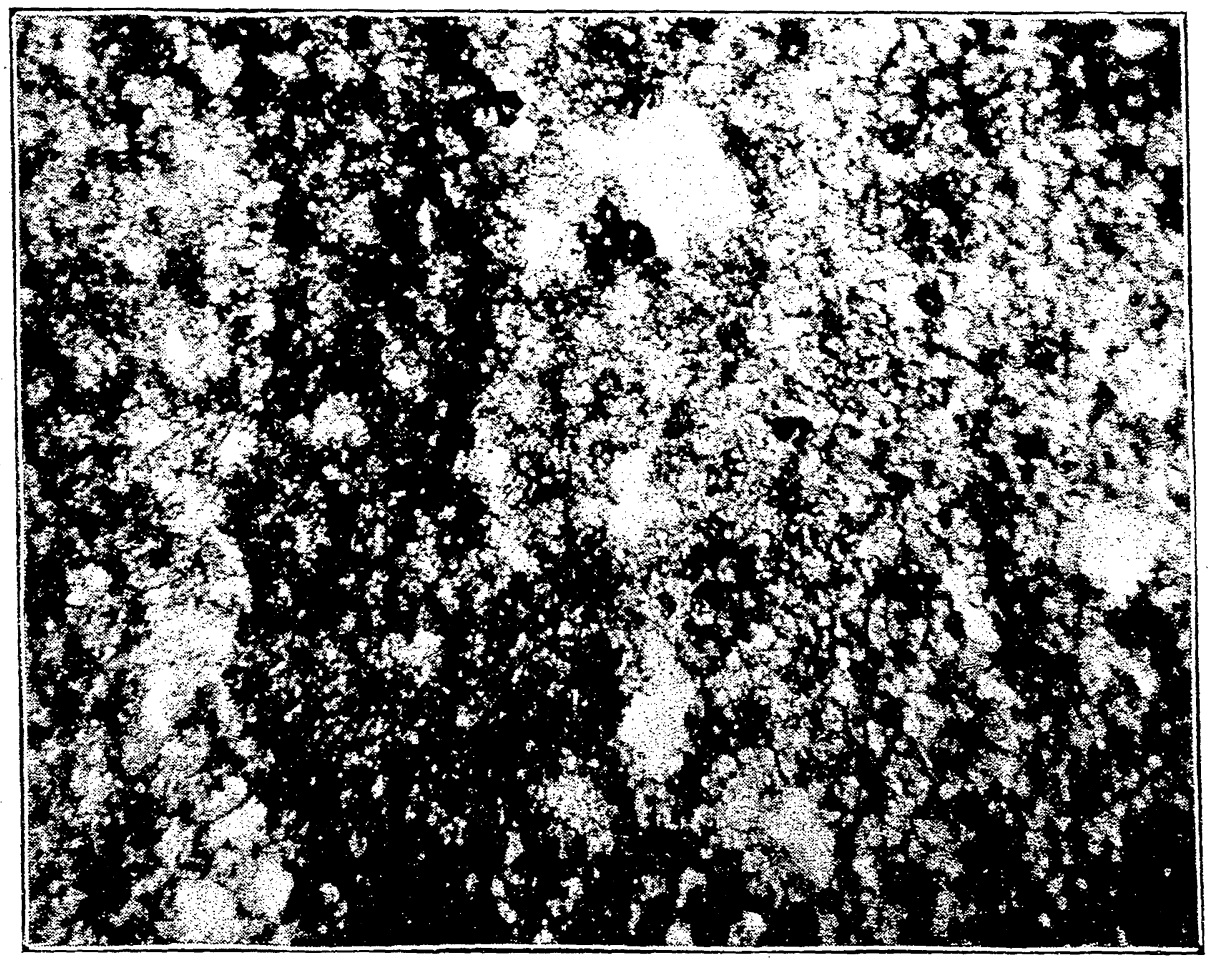

Fig 1 Microphotograph (x 80 , Animosa limestone, section cut across the bedding. Bedding planes rua ucross the figure from top to bottom, nutural light.

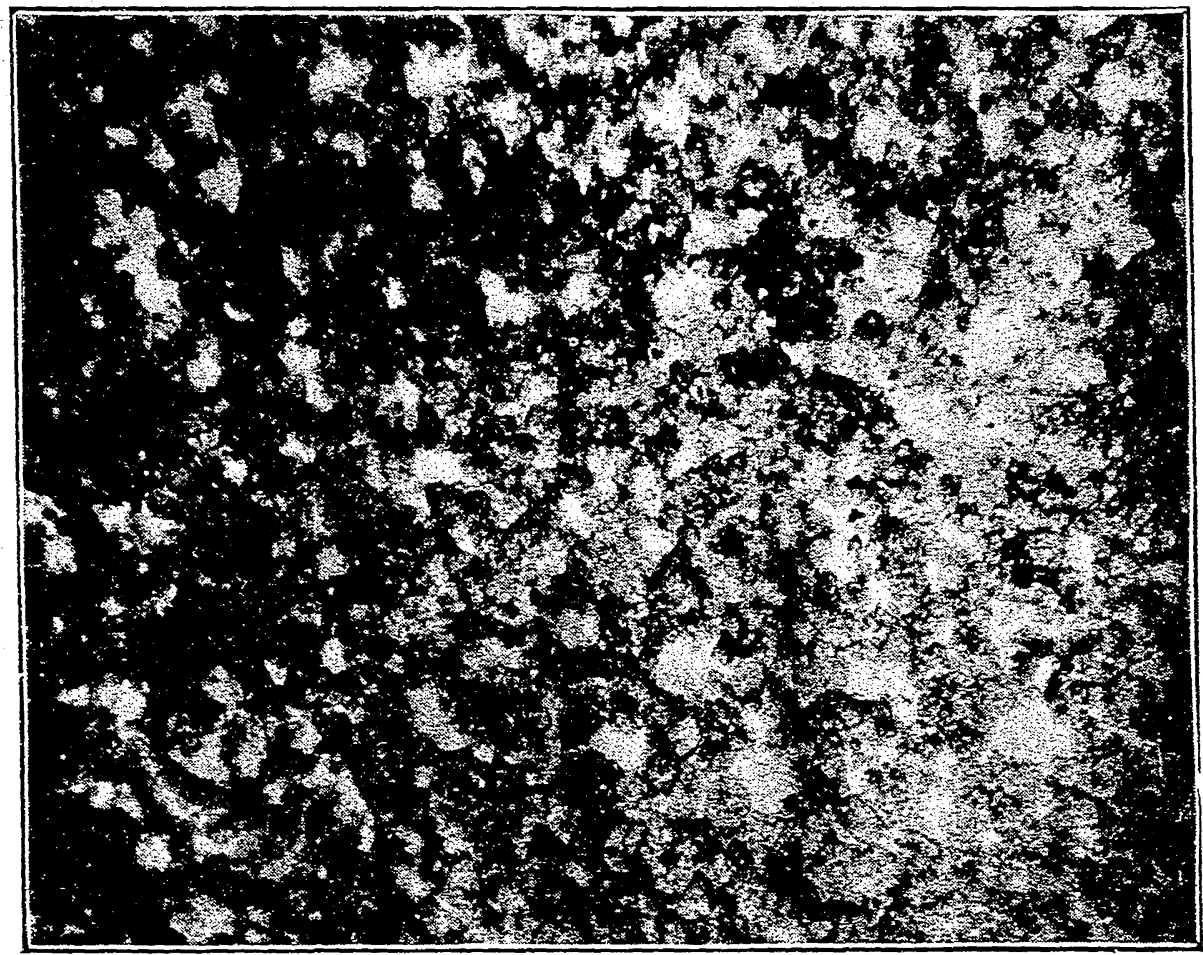

FIG 2 Microphotograph (x 80), Burlington limestone, sfetion cut parallel to bedding plane, nutural light. 
